\title{
A combined experimental and theoretical study of the synthesis of quinazolino[3,2-a][1,5]benzodiazepin-13-ones
}

\author{
Regina Janciene, ${ }^{\mathrm{a} *}$ Ausra Vektariene, ${ }^{\mathrm{b}}$ Gema Mikulskiene, ${ }^{\mathrm{a}}$ Tomas Javorskis, ${ }^{\mathrm{a}}$ Gytis \\ Vektaris, ${ }^{b}$ and Algirdas Klimavicius ${ }^{a}$ \\ ${ }^{a}$ Vilnius University Institute of Biochemistry, Mokslininku 12, LT-08662 Vilnius, Lithuania \\ ${ }^{b}$ Vilnius University Institute of Theoretical Physics and Astronomy, A. Gostauto 12, LT-01108 \\ Vilnius, Lithuania \\ E-mail: regina.janciene@bchi.vu.lt
}

\begin{abstract}
A simple and efficient general approach to various tetracyclic 6,7-dihydroquinazolino[3,2a] [1,5]benzodiazepin-13(5H)-ones has been demonstrated by reductive $\mathrm{N}$-heterocyclization of 5alkyl- or benzoyl-1-(2-nitrobenzoyl)-1,3,4,5-tetrahydro-2H-1,5-benzodiazepin-2-ones. These 2nitrobenzoylamides were obtained by acylation of the starting 5-alkyl- or benzoyl-1,5benzodiazepin-2-ones with 2-nitrobenzoyl chloride. A theoretical understanding of the features of the reductive $\mathrm{N}$-heterocyclization reaction was provided by means of quantum chemical reactivity descriptors calculations.
\end{abstract}

Keywords: Dihydroquinazolino[3,2-a][1,5]benzodiazepine, 1-(2-nitrobenzoyl)-1,3,4,5tetrahydro-2H-1,5-benzodiazepin-2-one, reductive heterocyclization, quantum-chemistry calculations

\section{Introduction}

Naturally occurring alkaloids such as asperlicins, circumdatins, benzomalvins and sclerotigenin incorporating a quinazolino[1,4]benzodiazepine system in their structure have been isolated from different sources. ${ }^{1}$ These alkaloids display various biological activities. In a quest to find additional potential quinazoline-based derivatives, various substituted quinazolinones,3 and compounds encompassing a quinazolino[1,4]benzodiazepine moiety in their skeleton ${ }^{4-7}$ have been developed.

As a part of our ongoing research activity, ${ }^{8-10}$ we were interested in the synthesis of some quinazolino[1,5]benzdiazepine derivatives as possible analogues of natural products. The main synthetic routes to compounds with quinazolino[1,4]benzodiazepine moiety utilize the implementations of 2-azidobenzoylamides in aza-Wittig methodology ${ }^{4,5,11}$ and transition metal- 
induced reductive $\mathrm{N}$-heterocyclization ${ }^{2,3,6,7,12}$ for the construction of a variety of heterocyclic compounds. Although these methods have emerged as versatile strategies, they have some disadvantages such as cost and availability of the reagents such as 2-azidobenzoyl chloride and noble metal catalysts.

As a continuation of our interest in polycyclic 1,5-benzodiazepines, we investigated the synthesis of novel quinazolino[3,2-a][1,5]benzodiazepine derivatives with potential biological activity. ${ }^{13,14}$ The heteroannelation was achieved by coupling the bicyclic 1,5-benzodiazepinones with 2-nitrobenzoyl chloride followed by a reductive $\mathrm{N}$-heterocyclization. The structural features of both quinazolino[3,2-a][1,5]benzodiazepines and $N$-(2-nitrobenzoyl)-1,5-benzodiazepin-2ones are discussed herein. Also, in the present study, the initial assessment of possible reaction intermediates was carried out and quantum-chemical reactivity descriptors were calculated to clarify the outcome of the reductive N-heterocyclization of nitrobenzoylamides.

\section{Results and Discussion}

A simple synthetic route for the preparation of 6,7-dihydroquinazolino[3,2$a][1,5]$ benzodiazepines 3 is depicted in Scheme 1. The first step of this strategy comprises the interaction of the starting 5-(benzoyl, benzyl, methyl) substituted-tetrahydro-1,5-benzodiazepin2-ones with 2-nitrobenzoyl- or 5-acetylamino-2-nitrobenzoyl chlorides.

Thus, benzoylation of lactams 1a-i with freshly prepared 2-nitrobenzoyl chloride in the presence of $\mathrm{N}, \mathrm{N}$-diisopropylethylamine (DIPEA) and the catalytic amount of 4dimethylaminopyridine (DMAP) in dry dichlorethane (DCE) at room temperature afforded corresponding nitro benzoylamides $\mathbf{2 a - i}$. The compounds of structure $\mathbf{2}$ were isolated in acceptable $42-65 \%$ yields after chromatographic purification. It should be noted that several experimental parameters were explored with the aim to obtain much higher yields of products 2 . The attempts to achieve a better yield of this transformation by increasing the reaction temperature (refluxing in different solvents) and prolonging the reaction time and usage of various quantities of the catalyst (DMAP) and acid chloride were not successful. Continuing our interest in this benzoylation reaction, we investigated the interaction of 1,5-benzodiazepin-2-ones 1a-c with 5-acetylamino-2-nitrobenzoyl chloride under analogous conditions. This interaction led to acetylamino-substituted amides 4a-c in $20-25 \%$ yields. We think that rather low yields of isolated products $\mathbf{4 a - c}$ is a result of their very poor solubility in usual solvents ( $\mathrm{DCE}, \mathrm{CHCl}_{3}$, ethyl acetate, benzene) and their complicated separation from the side products (e.g., DIPEA $\mathrm{HCl}$ salt). In addition, 5-acetylamino-2-nitrobenzoyl chloride was prepared according to the procedure $^{15}$ and used without further purification. 


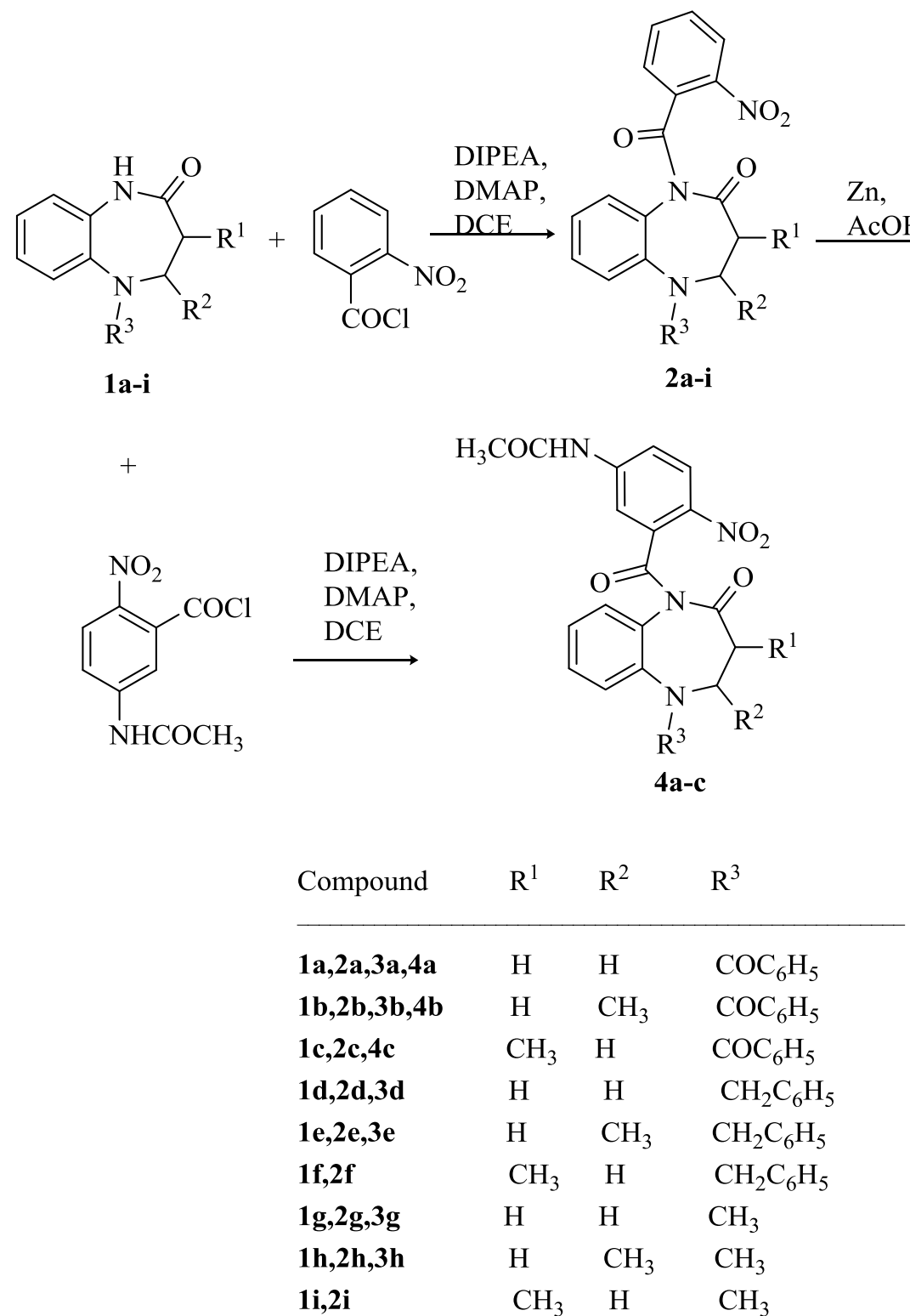

Scheme 1. Synthesis of quinazolino[3,2-a][1,5]benzodiazepin-13-ones.

As the second step in this investigation, we studied the reductive N-heterocyclization of precursors 2a-i and 4a-c. Recently, only a few examples of the catalytic reductive cyclization of $\mathrm{N}$-(2-nitrobenzoyl)amides to the corresponding quinazolino[1,5]benzodiazepines have been reported by us. ${ }^{16}$ Herein, we report the use of zinc dust in glacial acetic acid at room temperature for the reduction of nitro compounds $\mathbf{2}$ and $\mathbf{4}$. As planned in Scheme 1, this process in the case of compounds $\mathbf{2 a}, \mathbf{b}, \mathbf{d}, \mathbf{e}, \mathbf{g}, \mathbf{h}$ was nicely accompanied by a simultaneous N-heterocyclization to give 6,7-dihydroquinazolino[3,2-a][1,5]benzodiazepines 3a,b,d,e,g,h. It should be noted that during this process the formation of the corresponding amino derivatives was not observed (TLC). The polycyclic compounds 3a,b,e,h were obtained in good 68-97\% yields, whereas compounds $\mathbf{3 d}$ 
and $\mathbf{3 g}$ were isolated only in $30-32 \%$ yields. Due to their poor solubility and instability in heterocyclization reaction conditions (acetic acid), acetylamino-substituted amides 4a-c were unsuitable models for the study of this reaction.

Starting compounds 1a-c were easily obtained by the benzoylation of the corresponding 1,3,4,5-tetrahydro- $2 H$-1,5-benzodiazepin-2-ones according to the procedure. ${ }^{17}$ Precursors $1 \mathbf{d}$-i were previously described by us. ${ }^{18}$

The structures of the studied compounds were investigated using IR and NMR spectroscopy. The IR spectra of amides 2a-i and 4a-c show typical bands at $3361-3383 \mathrm{~cm}^{-1}$ for the NH (compounds 4a-c), $1645-1729 \mathrm{~cm}^{-1}$ for two or three $\mathrm{C}=\mathrm{O}$ and $1500-1530 \mathrm{~cm}^{-1}$ and $1332-1350$ $\mathrm{cm}^{-1}$ for the $\mathrm{NO}_{2}$ stretching vibrations. All examined quinazolinones 3 showed one or two (compounds 3a,b) bands in the region of carbonyl group absorption at $1641-1691 \mathrm{~cm}^{-1}$ and $\mathrm{C}=\mathrm{N}$ bond absorption peak at $1609-1611 \mathrm{~cm}^{-1}$.

For easier comparison of NMR data, the arbitrary numbering of atoms is presented in Figure 1 (A - for compounds $\mathbf{2 a - i , ~} \mathbf{B}$ - for compounds $\mathbf{3 a}, \mathbf{3 b}, \mathbf{3 d}, \mathbf{3 e}, \mathbf{3 g}$, 3h and $\mathbf{C}$ - for compounds 4a-c).

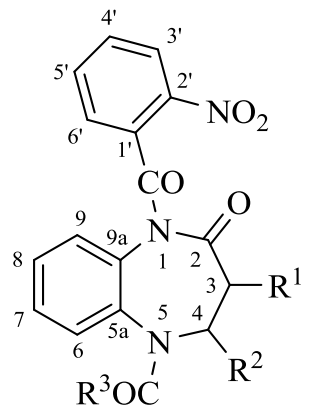

A

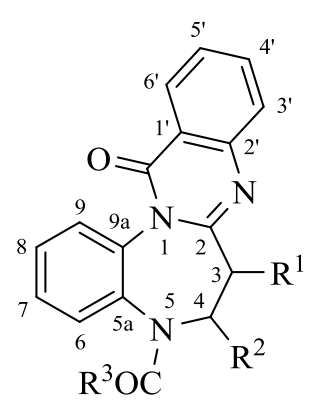

B

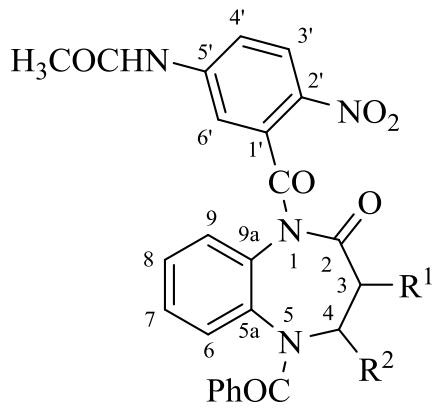

$\mathrm{C}$

Figure 1. Arbitrary numbering for the analysis of NMR data.

The ${ }^{1} \mathrm{H}$ NMR spectra of starting compounds $\mathbf{1 a - c}$, as well as of previously described $\mathbf{1 d - i}{ }^{18}$ exhibited the signals of aliphatic protons $\left(\mathrm{CH}_{3}, \mathrm{CH}_{2}\right.$ or $\mathrm{CH}$ groups) of the heptatomic ring, the characteristic $\mathrm{NH}$ singlet at about $9.0 \mathrm{ppm}$ and the resonances of aromatic protons in the range of 6.7-7.2 ppm integrated for nine protons. ${ }^{13} \mathrm{C}$ NMR spectra of 1a-c, in addition to the unambiguously assigned aromatic and aliphatic carbon resonances, revealed two appropriate downfield lying lines at 170.2-171.0 ppm (5-CO) and 173.6-175.7 ppm (C-2).

The missing $\mathrm{NH}$ singlet and the appearance of four additional aromatic protons in ${ }^{1} \mathrm{H}$ NMR spectra pointed to the formation of compounds 2a-i. The characteristic most downfield signal in the aromatic region at $\sim 8.3 \mathrm{ppm}$ was ascribed to $\mathrm{CH}-3^{\prime}$ using the $\mathrm{HMBC}$ spectra. ${ }^{13} \mathrm{C}$ NMR spectra of 2a-c, compared to spectra of 1a-c, showed the typical resonances with almost the same chemical shift values (169.7-170.9 ppm) for 5-CO, upfield shifted 1.9-3.0 ppm for C-2 and the new signals at $\sim 134.7 \mathrm{ppm}, \sim 144.5 \mathrm{ppm}$ and $\sim 167.7 \mathrm{ppm}$ assigned to $\mathrm{C}-1^{\prime}, \mathrm{C}-2^{\prime}$ and 1-CO, 
respectively. The presence of diastereotopic methylene protons $\left(5-\mathrm{CH}_{2}\right)$ which resonances formed characteristic $\mathrm{AB}$ quartet at $\sim 4.3 \mathrm{ppm}$ and $\sim 4.5 \mathrm{ppm}$ in ${ }^{1} \mathrm{H}$ NMR spectra and the absence of the resonance of 5-CO group carbon in ${ }^{13} \mathrm{C}$ NMR spectra were intrinsic to compounds $2 \mathbf{d}-\mathbf{f}$ compared to 2a-c. ${ }^{1} \mathrm{H}$ and ${ }^{13} \mathrm{C}$ NMR spectra of compounds 2 g-i showed the presence of 5- $\mathrm{CH}_{3}$ group which resonated at $2.8 \mathrm{ppm}$ and $39.4 \mathrm{ppm}$, respectively. Broadened resonances of aliphatic and some of aromatic moieties were observed in the case of compounds $2 \mathrm{~d}, \mathbf{2 g}, \mathbf{2 h}$ in ${ }^{1} \mathrm{H}$ and ${ }^{13} \mathrm{C}$ NMR spectra possibly due to the slow dynamic processes of heterocycle ring compared to the NMR time scale.

The above mentioned facts can be applied to prove the structure of compounds 4a-c. In addition, two new resonances, singlets at $2.1 \mathrm{ppm}\left(\mathrm{COCH}_{3}\right)$ and $10.7 \mathrm{ppm}\left(5^{\prime}-\mathrm{NH}\right)$, were observed in ${ }^{1} \mathrm{H}$ NMR spectra of compounds 4a-c. The resonances in ${ }^{13} \mathrm{C}$ NMR spectra of compounds 4a-c at $136.5 \mathrm{ppm}, 137.8 \mathrm{ppm}$ and $145.4 \mathrm{ppm}$ were attributed to $1^{\prime}-$-, 2'-, 5'- aryl ring carbons, respectively, and the resonance at $169.6 \mathrm{ppm}$ was attributed to $5^{\prime}$-NHCO carbon atom. These assignments were made by detailed analysis of HMBC spectra.

The essential feature of the formation of the compounds of structure $\mathbf{3}$ was the missing signal of C-2 (carbonyl group) at $\sim 172.8 \mathrm{ppm}$ and the appearance of resonance at $\sim 154.0 \mathrm{ppm}(\mathbf{3 a}, \mathbf{b})$ and $\sim 156.1 \mathrm{ppm}(\mathbf{3 d}, \mathbf{e}, \mathbf{g}, \mathbf{h})$ attributed to $\mathrm{C}=\mathrm{N}$ group carbon compared to the corresponding ${ }^{13} \mathrm{C}$ NMR spectra of compounds 2. The resonances of 1-CO group were shifted upfield by approximately $7 \mathrm{ppm}$ and were observed in the range of 160.6-160.9 ppm, the resonances of C-1' carbon were shifted upfield $\sim 13.4 \mathrm{ppm}$ and those of C-2' downfield $\sim 2.2 \mathrm{ppm}$. The most deshielded proton (at $\sim 8.3 \mathrm{ppm}$ ) in the aromatic region was assigned to $\mathrm{CH}-6$ ' in ${ }^{1} \mathrm{H}$ NMR spectra in the case of compounds 3 .

It should be noted that the reductive cyclization carried out with derivatives $\mathbf{2 c}, \mathbf{f}, \mathbf{i}$ under analogous conditions was unsuccessful. Nitro derivatives $\mathbf{2 c , f , \mathbf { i }}(\sim 50 \%)$ and starting lactams

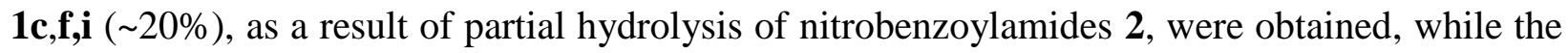
corresponding amino compounds were not isolated. Thus, 1-nitrobenzoylated derivatives $\mathbf{2 c}, \mathbf{f}, \mathbf{i}$ bearing the methyl substituent in the 3-position of the diazepine nucleus behaved differently in comparison with nitrobenzoylamides $\mathbf{2 a}, \mathbf{2 b}, \mathbf{2 d}, \mathbf{2 e}, \mathbf{2 g}, \mathbf{2 h}$ which had no substituents or had the methyl substituent in the 4-position of heptatomic moiety. These differences can not be explained entirely by the steric hindrance caused by 3-methyl group. The steric influence of 3methyl group was not observed in our previous study of the synthesis of imidazo[1,2- $a]$ and thiazolo[3,2-a][1,5]benzodiazepine derivatives. ${ }^{8,9}$ Moreover, it is well known that the steric hindrance effects of bulky methyl group most often affects reactivity behaviors in the less flexible aromatic system or in the molecular systems bearing conjugated delocalized $\pi$ bonding. ${ }^{19,20}$ While in this reductive heterocyclization the heptatomic diazepine ring bearing 3methyl group can easily change configuration due to flexible $\sigma$ bonding system. In this way molecular self-regulation of reacting molecular system (in our case 1-nitrobenzoylated derivatives $2 \mathbf{c}, \mathbf{f}, \mathbf{i})$ could lead to the geometry changes that avoids the steric hindrance effects of reacting centre. 
It is worth mentioning that the mechanism for the reduction of nitro compounds has been the subject of many investigations and there is considerable evidence that this reaction proceeds stepwise through a number of intermediates including nitroso and hydroxylamine derivatives that were detected in the reaction mixture. ${ }^{21,22}$ However, the theoretical understanding of the reduction occurring with simultaneous heterocyclization process is not established well. To identify which reaction step is important for the initiation of heterocyclization reaction, we focused our efforts on the estimation of possible reaction intermediates by means of quantumchemical reactivity descriptors calculations.

We suggested the possible reaction mechanism scenario for this heterocyclization and presented it in Scheme 2.

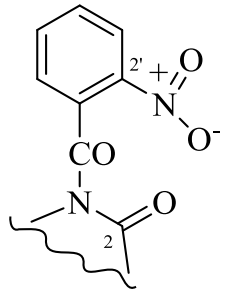

$\mathbf{2 a - i}$

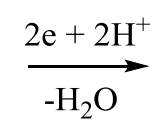

$-\mathrm{H}_{2} \mathrm{O}$$$
\text { (1) }
$$

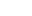


water molecules afforded the $\mathrm{C}=\mathrm{N}$ double bond and final products $\mathbf{3 a}, \mathbf{3 b}, \mathbf{3 d}, \mathbf{3 e}, \mathbf{3 g}, \mathbf{3 h}$. The presented reaction mechanism (Scheme 2) demonstrates that the initiation of heterocyclization reaction becomes possible after intermediate III is formed. Thus, the insight into the electronic structure of intermediate III can be of great importance for the explanation of different reactivity pattern of nitrobenzoylamides $\mathbf{2 a - i}$ in the reductive heterocyclization reaction. To confirm our assumptions, the theoretical investigation results of intermediates IIIa-i by means of quantum chemical reactivity descriptors calculations are presented in this article. Frontier molecular orbitals densities $^{23}$ and Mulliken (M), natural (N) and electrostatic potential derived charges (ESP) ${ }^{19,23-29}$ reflect the different behavior of these intermediates in the reductive heterocyclization process.

It is known that frontier orbital densities on atoms allow the estimation of donor-acceptor interactions that exist between different atoms in the same molecule. ${ }^{24}$ According to the frontier orbital reactivity theory, the majority of chemical reactions take place at the position and in the orientation where the overlap of the highest occupied molecular orbital (HOMO) and the lowest unoccupied molecular orbital (LUMO) of the respective reactants can reach the maximum. ${ }^{19,24-28}$ The charge distribution in the molecule most frequently predicts the interaction of electrostatic forces. ${ }^{19,23-28}$ Mulliken charges and natural charges show how much electron density is associated with each atom's orbitals. The ESP charges at the atom are chosen to best describe the electrostatic potential surrounding the molecule. The molecular ESP charges on the molecular electron density iso-surface are a good indicator for the interpretation of chemical reactivity. ${ }^{25-}$ ${ }^{27,29}$ Hence, it gives a suitable description of molecular properties, such as strong noncovalent interactions that are predominantly electrostatic in nature.

In our earlier quantum chemical reactivity descriptors studies of the substituted 1,5benzodiazepine-2-thiones interaction with bromoketones, the performance of the AM1 method and DFT B3LYP functional with two different basis sets $\left(6-31 \mathrm{G}^{*}\right.$ and $\left.6-31+\mathrm{G}^{*}\right)$ was compared and it was stated that both methods provided very similar results. ${ }^{29}$ The advantage of the AM1 model is that it is less time consuming. However, the DFT B3LYP model allows the calculation of more molecular quantum properties, offers better accuracy in the estimation of reactivity descriptors, ensures high reliability, and includes a broader diversity of descriptors. Hence, in the present computational study of heterocyclization reaction we used the AM1 and DFT B3LYP 6$31 \mathrm{G}^{*}$ methods. The first optimization of plausible intermediate structures was carried out with AM1 method. Consequently, the AM1 geometry optimized structures were used as initial coordinates for energy optimization at the DFT level using the B3LYP functional and 6-31G* basis sets. ${ }^{30}$ The vibrational frequencies were computed for optimized intermediate structures and checked to present no imaginary vibrational frequency to ensure that they were local minima points on the potential energy surface. ${ }^{20,31}$ The HOMO and LUMO densities were calculated according to the methods described in the literature. ${ }^{23}$

The calculated reactivity descriptors - M, N and ESP charges, HOMO and LUMO densities, for 3,4,5-substituted intermediates IIIa-i on the C(2) and 2'-N atoms are the most significant for the reaction progress. They are presented in Table 1 . To get the overall insight to the observed 
reactivity, the typical and the most important for the reaction progress HOMO and LUMO shapes of IIIa-c were selected from all calculated results of IIIa-i and pictured in Figure 2. Computation reveals that HOMOs of IIIa-i consist of identical shapes. Figure 2 demonstrates that the HOMO shapes for IIIa-c consist of out of plane $\pi$ orbitals located on the benzene ring of benzoylamide moiety and the lone pair orbital situated on the nitrogen 2'-N atom of the hydroxylamine group. The data presented in Table 1 supports the results of the pictured HOMO shapes showing that HOMO density values for 2'-N atom of all studied intermediates differ slightly and are in the range of 0.24-0.38, whereas differences in the shapes of LUMO of IIIa-i are observed. As shown in Figure 2, the LUMOs of 3,4- unsubstituted and 4-methyl substituted IIIa-b mainly consists of the antibonding out of plane $\pi$ orbital located on the $\mathrm{C}(2)-\mathrm{O}$ bond of the diazepine skeleton. The minor contribution to the LUMO shape occupancy of IIIa-b is located between the nitrogen $\mathrm{N}(1)$ atom of the diazepine skeleton and the carbon atom of 1-CO group in benzoylamide moiety. The magnitudes of densities and the phase of HOMO on the nitrogen 2'-N atom and on the $\mathrm{C}(2)$ atom of LUMO demonstrate the tendency in phase overlap between those molecular orbitals and allow bonding interaction between $\mathrm{C}(2)$ and 2'-N atoms for IIIa-b. The LUMO shapes of the 3-methyl substituted IIIc mainly consist of the antibonding out of plane $\pi$ orbital located on the carbonyl group of benzoylamide moiety and partly on the benzene ring annulated with the diazepine cycle (Figure 2). Meanwhile, the $\mathrm{C}(2)-\mathrm{O}$ bond on diazepine skeleton does not have noticeable shape for IIIc. Thus, in this case, the bonding overlap between the nitrogen $2^{\prime}-\mathrm{N}$ atom and the carbon $\mathrm{C}(2)$ atom is not promoted. This phenomenon is also revealed by the calculated values of LUMO densities for C(2) atom of IIIa-i presented in Table 1. There is a significant difference between the two intermediate groups: LUMO density values for IIIa,b,d,e,g,h are in the range of 0.35-0.53, whereas those for IIIc,f,i in the range of $0.05-0.15$.

The results presented in Table 1 show that the calculated M, N and ESP charges for IIIc,f,i bearing 3-methylgroup in heptatomic nucleus do not differ from those for the rest investigated intermediates IIIa,b,d,e,g,h. Therefore, it is possible to suggest that the charges do not play a significant role for this reaction step, whereas the calculated HOMO and LUMO shapes and density values suggest that heterocyclization reaction is controlled by frontier molecular orbitals. Moreover, our computational results reveal that the position of the substituents on the diazepine skeleton have the effect on the LUMO density changes on the IIIa-i. This suggests that the presence of the electron donating 3-methyl substituent decreases the electrophilicity of the $\mathrm{C}(2)$ atom and evokes resistance for further intramolecular rearrangements. 

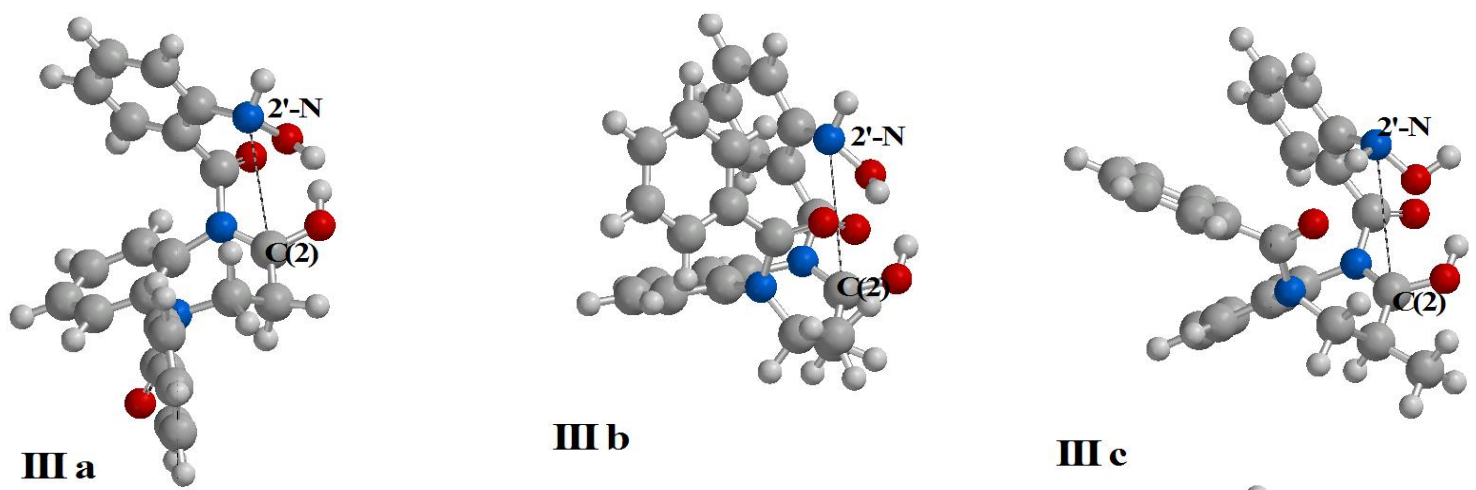

III b
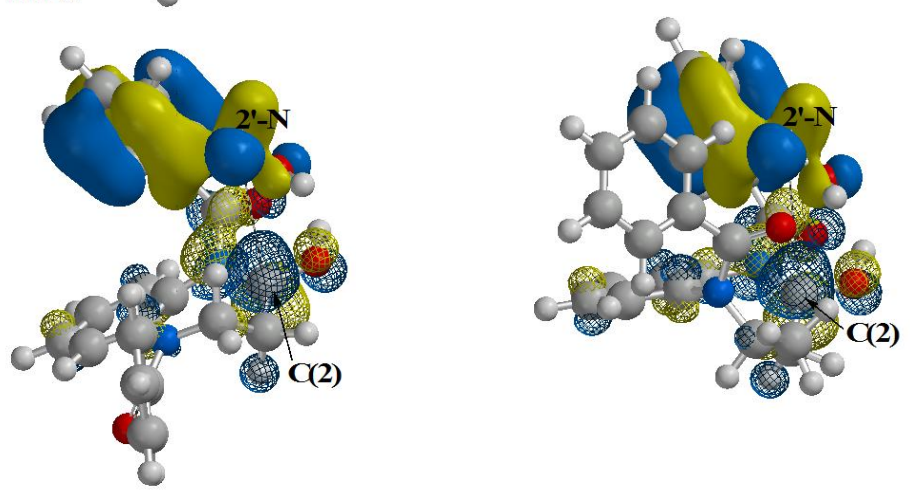

III c

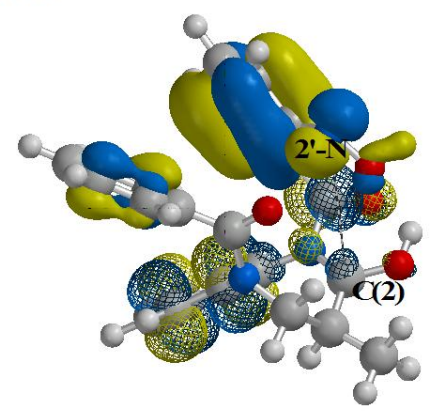

Figure 2. The optimal geometry of intermediates IIIa-c and HOMO(solid), LUMO(mesh) shapes.

Table 1. Calculated M, N and ESP charges, HOMO, LUMO densities for intermediates IIIa-i on $\mathrm{C}(2)$ and 2 '-N atoms

\begin{tabular}{lllllllll}
\hline & \multicolumn{3}{c}{$2^{\prime}-\mathrm{N}$} & \multicolumn{3}{c}{$\mathrm{C}(2)$} \\
\cline { 2 - 8 } Intermediate & $\mathrm{ESP}$ & $\mathrm{M}$ & $\mathrm{N}$ & HOMO & $\mathrm{ESP}$ & $\mathrm{M}$ & $\mathrm{N}$ & LUMO \\
\hline IIIa & -0.552 & -0.408 & -0.329 & 0.235 & 0.479 & 0.612 & 0.764 & 0.391 \\
IIIb & -0.381 & -0.399 & -0.321 & 0.289 & 0.585 & 0.651 & 0.784 & 0.415 \\
IIIc & -0.537 & -0.402 & -0.338 & 0.293 & 0.419 & 0.677 & 0.789 & 0.048 \\
IIId & -0.512 & -0.469 & -0.405 & 0.374 & 0.326 & 0.605 & 0.850 & 0.528 \\
IIIe & -0.384 & -0.357 & -0.289 & 0.314 & 0.667 & 0.631 & 0.748 & 0.350 \\
IIIf & -0.367 & -0.402 & -0.306 & 0.316 & 0.491 & 0.650 & 0.740 & 0.098 \\
IIIg & -0.436 & -0.432 & -0.391 & 0.376 & 0.651 & 0.641 & 0.757 & 0.453 \\
IIIh & -0.259 & -0.410 & -0.352 & 0.290 & 0.610 & 0.621 & 0.745 & 0.413 \\
IIIi & -0.330 & -0.411 & -0.353 & 0.298 & 0.478 & 0.629 & 0.754 & 0.150 \\
\hline
\end{tabular}


In conclusion, a series of new 6,7-dihydroquinazolino[3,2-a][1,5]benzodiazepin-13(5H)-ones was successfully synthesized using the reductive N-heterocyclization of 1-(2-nitrobenzoyl)1,3,4,5-tetrahydro-2H-1,5-benzodiazepin-2-ones. It was established that the course of this heterocyclization depended on the presence of substituents in the heptatomic ring of the starting heterocycles. The possible heterocyclization reaction mechanism was suggested. It was shown that the initiation of heterocyclization reaction in the reduction process became possible with the formation of intermediate IIIa-i. The calculated reactivity descriptors (frontier molecular orbitals densities, Mulliken, natural and electrostatic potential derived charges) of intermediates IIIa-i suggest that heterocyclization reaction is an intermolecular rearrangement strongly controlled by frontier molecular orbitals, whereas charges do not play a significant role for this reaction step. Moreover, our computational results reveal that the position of the substituent on the diazepine skeleton affect the changes in LUMO densities of IIIa-i, therefore this reactivity descriptor can be useful for characterization and prediction of the studied heterocyclization process.

\section{Experimental Section}

General. Melting points were determined in open capillaries on a MEL-TEMP 1202D apparatus and are uncorrected. The IR spectra (potassium bromide) were taken on a Perkin Elmer Spectrum GX FT-IR spectrometer. ${ }^{1} \mathrm{H}$ and ${ }^{13} \mathrm{C}$ NMR spectra were recorded on a Varian Unity Inova 300 and Bruker Ascend ${ }^{\mathrm{tm}} 400$ at $302 \mathrm{~K}$. Chemical shifts $(\delta)$ are reported relative to tetramethylsilane (TMS) with the solvent reference: $\mathrm{CDCl}_{3}(\delta 7.26 \mathrm{ppm}), \mathrm{DMSO}_{-} d_{6}(\delta 2.50$ ppm) for ${ }^{1} \mathrm{H}$ NMR and $\mathrm{CDCl}_{3}(\delta 77.0 \mathrm{ppm})$, DMSO- $d_{6}(\delta 39.50 \mathrm{ppm})$ for ${ }^{13} \mathrm{C} \mathrm{NMR}$. The values of chemical shifts are expressed in ppm and coupling constants $(J)$ in Hz. The assignments of ${ }^{13} \mathrm{C}$ NMR spectra were made with the aid of APT and HMBC experiments. Elemental analyses $(\mathrm{C}, \mathrm{H}$, $\mathrm{N})$ were performed on an Elemental Analyser CE-440. The reactions were controlled by the TLC method and performed on a Merck precoated silica gel aluminum roll $\left(60 \mathrm{~F}_{254}\right)$ with chloroformethyl acetate-methanol $(v / v, 14: 7: 1)$ as the eluent and was visualized with UV light. Dry column vacuum chromatography ${ }^{32}$ was performed with silica gel 60 (0.015-0.040 mm, Merck).

General procedure for the synthesis of 1 -(2-nitrobenzoyl)-3-R $R^{\mathbf{1}}-\mathbf{4}-\mathrm{R}^{\mathbf{2}}-\mathbf{5}-\mathrm{R}^{\mathbf{3}} \mathbf{- 1}, \mathbf{3 , 4 , 5}$ tetrahydro-2H-1,5-benzodiazepin-2-ones (2a-i). Freshly prepared o-nitrobenzoylchloride $(0.8$ $\mathrm{mL}, 6 \mathrm{mmol})$ in dry DCE $(6 \mathrm{~mL})$ was added dropwise to a stirred solution of appropriate benzodiazepinone 1a-i (5 mmol) in dry DCE (40-60 mL) containing DIPEA (1.05 mL, $6 \mathrm{mmol})$ and catalytic amount of DMAP at room temperature. The reaction mixture was stirred at room temperature for $24 \mathrm{~h}$. The reaction mixture was diluted with DCE $(60 \mathrm{~mL})$, washed with $1 \mathrm{n} \mathrm{HCl}$, $5 \% \mathrm{NaHCO}_{3}$ and water. After drying and removal of the solvent in vacuum, the oily residues were firstly subjected to dry column vacuum chromatography (silicagel) using the benzene-DCE system for gradient elution and recrystallized from dichloromethane-diethyl ether mixture to give 2a-i. 
5-Benzoyl-1-(2-nitrobenzoyl)-1,3,4,5-tetrahydro-2H-1,5-benzodiazepin-2-one (2a). White crystals, yield $1.14 \mathrm{~g}(55 \%), \mathrm{mp} 213-215^{\circ} \mathrm{C}$. IR: $v$ 1727, 1706, 1652 (CO), 1524, $1350\left(\mathrm{NO}_{2}\right)$ $\mathrm{cm}^{-1} .{ }^{1} \mathrm{H}$ NMR $\left(300 \mathrm{MHz}, \mathrm{CDCl}_{3}\right): \delta_{\mathrm{H}} 2.50\left(1 \mathrm{H}\right.$, ddd, $\left.J 1.4,4.7,13.6 \mathrm{~Hz}, 3-\mathrm{CH}_{2}\right), 2.71(1 \mathrm{H}, \mathrm{dt}, J$ 6.8, $\left.13.9 \mathrm{~Hz}, 3-\mathrm{CH}_{2}\right), 3.74\left(1 \mathrm{H}\right.$, ddd, $\left.J 1.6,6.8,12.9 \mathrm{~Hz}, 4-\mathrm{CH}_{2}\right), 4.64(1 \mathrm{H}, \mathrm{dt}, J$ 4.8, $13.7 \mathrm{~Hz}, 4-$ $\left.\mathrm{CH}_{2}\right), 6.83\left(1 \mathrm{H}_{\text {arom }}, \mathrm{dd}, J 1.1,7.9 \mathrm{~Hz}, \mathrm{CH}\right), 7.17-7.45\left(8 \mathrm{H}_{\text {arom }}, \mathrm{m}, \mathrm{CH}\right), 7.63\left(1 \mathrm{H}_{\text {arom }}\right.$, ddd. $J$ 1.4, 7.5, 8.4 Hz, CH), $7.73\left(1 \mathrm{H}_{\text {arom }}, \mathrm{dd}, J 1.3,8.0 \mathrm{~Hz}, \mathrm{CH}\right), 7.76\left(1 \mathrm{H}_{\text {arom }}, \mathrm{dt}, J 1.2,7.5 \mathrm{~Hz}, 5^{\prime}-\mathrm{CH}\right), 8.29$ $\left(1 \mathrm{H}_{\text {arom }}, \mathrm{dd}, J 1.1,8.3 \mathrm{~Hz}, 3^{\prime}-\mathrm{CH}\right) .{ }^{13} \mathrm{C} \mathrm{NMR}\left(75 \mathrm{MHz}, \mathrm{CDCl}_{3}\right): \delta_{\mathrm{C}} 35.0(\mathrm{C}-3), 47.3(\mathrm{C}-4), 124.3$ $(\mathrm{CH}), 126.8(\mathrm{CH}), 128.2\left(m-\mathrm{CH}_{\mathrm{Ph}}\right), 128.3(\mathrm{CH}), 129.1\left(o-\mathrm{CH}_{\mathrm{Ph}}\right), 129.1(\mathrm{CH}), 129.7(2 \mathrm{CH}), 129.8$ $(\mathrm{CH}), 130.8\left(p-\mathrm{CH}_{\mathrm{Ph}}\right), 133.9\left(i-\mathrm{C}_{\mathrm{Ph}}\right), 134.2\left(\mathrm{C}-5 \mathrm{a}\right.$ or C-9a), $134.6\left(\mathrm{C}-1^{\prime}\right), 134.6(\mathrm{CH}), 137.0(\mathrm{C}-9 \mathrm{a}$ or C-5a), 144.6 (C-2'), 167.6 (1-CO), 170.9 (5-CO), 171.1 (C-2). Anal. Calcd. for $\mathrm{C}_{23} \mathrm{H}_{17} \mathrm{~N}_{3} \mathrm{O}_{5}$ (415.40): C, 66.50; H, 4.12; N, 10.12\%. Found: C, 66.31; H, 4.22; N, 10.35\%.

5-Benzoyl-4-methyl-1-(2-nitrobenzoyl)-1,3,4,5-tetrahydro-2H-1,5-benzodiazepin-2-one (2b). White crystals, yield $1.20 \mathrm{~g}$ (56\%), mp 205-207 ${ }^{\circ} \mathrm{C}$. IR: $v$ 1729, 1707, 1651 (CO), 1525, 1349 $\left(\mathrm{NO}_{2}\right) \mathrm{cm}^{-1} .{ }^{1} \mathrm{H}$ NMR $\left(400 \mathrm{MHz}, \mathrm{CDCl}_{3}\right): \delta_{\mathrm{H}} 1.24\left(3 \mathrm{H}, \mathrm{d}, J 6.2 \mathrm{~Hz}, 4-\mathrm{CH}_{3}\right), 2.37(1 \mathrm{H}, \mathrm{dd}, J 12.1$, $\left.13.1 \mathrm{~Hz}, 3-\mathrm{CH}_{2}\right), 2.45\left(1 \mathrm{H}, \mathrm{dd}, J 5.7,13.2 \mathrm{~Hz}, 3-\mathrm{CH}_{2}\right), 5.16\left(1 \mathrm{H}, \mathrm{qt}, J 5.9,11.5 \mathrm{~Hz}, 4-\mathrm{CH}_{2}\right), 6.80$ $\left(1 \mathrm{H}_{\text {arom }}, \mathrm{d}, J\right.$ 7.1 Hz, CH), 7.18-7.78 $\left(11 \mathrm{H}_{\text {arom }}, \mathrm{m}, \mathrm{CH}\right), 8.28\left(1 \mathrm{H}_{\text {arom }}, \mathrm{dd}, J 0.9,8.3 \mathrm{~Hz}, 3^{\prime}-\mathrm{CH}\right)$. ${ }^{13} \mathrm{C} \mathrm{NMR}\left(100 \mathrm{MHz}, \mathrm{CDCl}_{3}\right): \delta_{\mathrm{C}} 18.0\left(4-\mathrm{CH}_{3}\right), 42.5(\mathrm{C}-3), 53.7(\mathrm{C}-4), 124.3(\mathrm{CH}), 126.9(\mathrm{CH})$, $128.1\left(o-\mathrm{CH}_{\mathrm{Ph}}\right), 128.6(\mathrm{CH}), 128.8\left(m-\mathrm{CH}_{\mathrm{Ph}}\right), 129.0(\mathrm{CH}), 129.3(\mathrm{CH}), 129.8(\mathrm{CH}), 130.5(p-$ $\left.\mathrm{CH}_{\mathrm{Ph}}\right), 131.0(\mathrm{CH}), 134.6\left(i-\mathrm{C}_{\mathrm{Ph}}\right), 134.6(\mathrm{CH}), 134.7$ (C-5a or C-9a), $134.8\left(\mathrm{C}-1^{\prime}\right), 134.8(\mathrm{C}-9 \mathrm{a}$ or C-5a), 144.5 (C-2'), 167.8 (1-CO), 169.8 (5-CO), 170.7 (C-2). Anal. Calcd. for $\mathrm{C}_{24} \mathrm{H}_{19} \mathrm{~N}_{3} \mathrm{O}_{5}$ (429.43): C, 67.13; H, 4.46; N, 9.79\%. Found: C, 67.31; H, 4.59; N, 9.61\%.

5-Benzoyl-3-methyl-1-(2-nitrobenzoyl)-1,3,4,5-tetrahydro-2H-1,5-benzodiazepin-2-one (2c). White crystals, yield $1.01 \mathrm{~g}(47 \%), \mathrm{mp} 211-213{ }^{\circ} \mathrm{C}$. IR: $v$ 1726, 1706, 1645 (CO), 1525, 1344 $\left(\mathrm{NO}_{2}\right) \mathrm{cm}^{-1} .{ }^{1} \mathrm{H}$ NMR $\left(300 \mathrm{MHz}, \mathrm{CDCl}_{3}\right): \delta_{\mathrm{H}} 1.08\left(3 \mathrm{H}, \mathrm{d}, J 6.5 \mathrm{~Hz}, 3-\mathrm{CH}_{3}\right), 2.85(1 \mathrm{H}, \mathrm{pd}, J$ 6.4, $12.7 \mathrm{~Hz}, 3-\mathrm{CH}), 3.69\left(1 \mathrm{H}, \mathrm{dd}, J 6.3,12.8 \mathrm{~Hz}, 4-\mathrm{CH}_{2}\right), 4.30\left(1 \mathrm{H}, \mathrm{t}, J 12.9 \mathrm{~Hz}, 4-\mathrm{CH}_{2}\right), 6.85$ $\left(1 \mathrm{H}_{\text {arom }}, \mathrm{dd}, J 1.1,7.9 \mathrm{~Hz}, \mathrm{CH}\right), 7.19-7.81\left(11 \mathrm{H}_{\text {arom }}, \mathrm{m}, \mathrm{CH}\right), 8.31\left(1 \mathrm{H}_{\text {arom }}, \mathrm{dd}, J 1.1,8.3 \mathrm{~Hz}, 3^{\prime}-\right.$ $\mathrm{CH}) .{ }^{13} \mathrm{C}$ NMR $\left(75 \mathrm{MHz}, \mathrm{CDCl}_{3}\right): \delta_{\mathrm{C}} 12.4\left(3-\mathrm{CH}_{3}\right), 37.4(\mathrm{C}-3), 54.3(\mathrm{C}-4), 124.3(\mathrm{CH}), 126.7$ $(\mathrm{CH}), 128.1\left(m-\mathrm{CH}_{\mathrm{Ph}}\right), 128.2(\mathrm{CH}), 129.1\left(o-\mathrm{CH}_{\mathrm{Ph}}\right), 129.2(\mathrm{CH}), 129.3(\mathrm{CH}), 129.6(\mathrm{CH}), 129.7$ $(\mathrm{CH}), 130.8\left(p-\mathrm{CH}_{\mathrm{Ph}}\right), 133.5\left(i-\mathrm{C}_{\mathrm{Ph}}\right), 134.2\left(\mathrm{C}-5 \mathrm{a}\right.$ or C-9a), $134.6(\mathrm{CH}), 134.9\left(\mathrm{C}-1^{\prime}\right), 137.7(\mathrm{C}-9 \mathrm{a}$ or C-5a), 144.5 (C-2'), 167.8 (1-CO), 170.7 (5-CO), 173.8 (C-2). Anal. Calcd. for $\mathrm{C}_{24} \mathrm{H}_{19} \mathrm{~N}_{3} \mathrm{O}_{5}$ (429.43): C, 67.13; H, 4.46; N, 9.79\%. Found: C 66.89; H 4.31; N 10.01\%.

5-Benzyl-1-(2-nitrobenzoyl)-1,3,4,5-tetrahydro-2H-1,5-benzodiazepin-2-one (2d). Yellowish solid, yield $0.84 \mathrm{~g}(42 \%)$, mp 59-61 ${ }^{\circ} \mathrm{C}$. IR: $v$ 1725, 1699 (CO), 1527, $1348\left(\mathrm{NO}_{2}\right) \mathrm{cm}^{-1} .{ }^{1} \mathrm{H}$ NMR $\left(400 \mathrm{MHz}, \mathrm{CDCl}_{3}\right): \delta_{\mathrm{H}} 2.27\left(1 \mathrm{H}, \mathrm{br}, 3-\mathrm{CH}_{2}\right), 2.62\left(1 \mathrm{H}, \mathrm{br}, 3-\mathrm{CH}_{2}\right), 2.89\left(1 \mathrm{H}, \mathrm{br}, 4-\mathrm{CH}_{2}\right), 3.47$ $\left(1 \mathrm{H}, \mathrm{br}, 4-\mathrm{CH}_{2}\right), 4.08\left(1 \mathrm{H}, \mathrm{br}, 5-\mathrm{CH}_{2}\right), 4.49\left(1 \mathrm{H}, \mathrm{br}, 5-\mathrm{CH}_{2}\right), 7.22-7.62\left(11 \mathrm{H}_{\text {arom }}, \mathrm{m}, \mathrm{CH}\right), 7.73$ $\left(1 \mathrm{H}_{\text {arom }}, \mathrm{dt}, J 1.2,7.5 \mathrm{~Hz}, 5^{\prime}-\mathrm{CH}\right), 8.27\left(1 \mathrm{H}_{\text {arom }}\right.$, dd, $\left.J 0.4,8.3 \mathrm{~Hz}, 3^{\prime}-\mathrm{CH}\right) .{ }^{13} \mathrm{C} \mathrm{NMR}(100 \mathrm{MHz}$, $\left.\mathrm{CDCl}_{3}\right): \delta_{\mathrm{C}} 35.9(\mathrm{C}-3), 53.6(\mathrm{C}-4), 57.2\left(5-\mathrm{CH}_{2}\right), 120.8(\mathrm{CH}), 123.8(\mathrm{CH}), 124.2(\mathrm{CH}), 126.4$ $(\mathrm{CH}), 127.5\left(p-\mathrm{CH}_{\mathrm{Ph}}\right), 128.3\left(m-\mathrm{CH}_{\mathrm{Ph}}\right), 128.4(\mathrm{CH}), 128.6\left(o-\mathrm{CH}_{\mathrm{Ph}}\right), 129.3(\mathrm{CH}), 129.7(\mathrm{CH})$, 132.0 (C-5a or C-9a), $134.3(\mathrm{CH}), 135.5\left(\mathrm{C}-1^{\prime}\right), 137.3\left(i-\mathrm{C}_{\mathrm{Ph}}\right), 143.9$ (C-9a or C-5a), $144.7(\mathrm{C}-$ 
2'), 167.3 (1-CO), 172.4 (C-2). Anal. Calcd. for $\mathrm{C}_{23} \mathrm{H}_{19} \mathrm{~N}_{3} \mathrm{O}_{4}$ (401.42): C 68.82; H, 4.77; N, $10.47 \%$. Found: C, 69.02; H, 4.61; N, 10.19\%.

5-Benzyl-4-methyl-1-(2-nitrobenzoyl)-1,3,4,5-tetrahydro-2H-1,5-benzodiazepin-2-one (2e). Orange crystals, yield $1.3 \mathrm{~g}(62 \%), \mathrm{mp} 165-166{ }^{\circ} \mathrm{C}$. IR: $v$ 1725, $1700(\mathrm{CO}), 1527,1346\left(\mathrm{NO}_{2}\right)$ $\mathrm{cm}^{-1} .{ }^{1} \mathrm{H}$ NMR $\left(300 \mathrm{MHz}, \mathrm{CDCl}_{3}\right): \delta_{\mathrm{H}} 0.95\left(3 \mathrm{H}, \mathrm{d}, J 6.1 \mathrm{~Hz}, 4-\mathrm{CH}_{3}\right), 2.22-2.35\left(1 \mathrm{H}, \mathrm{m}, 3-\mathrm{CH}_{2}\right)$, $3.77(1 \mathrm{H}, \mathrm{m}, 4-\mathrm{CH}), 4.42$ and $4.27\left(2 \mathrm{H}, \mathrm{ABq}, J 14.0 \mathrm{~Hz}, 5-\mathrm{CH}_{2}\right), 7.21-7.61\left(11 \mathrm{H}_{\text {arom }}, \mathrm{m}, \mathrm{CH}\right)$, $7.73\left(1 \mathrm{H}_{\text {arom }}, \mathrm{dt}, J 1.2,7.5 \mathrm{~Hz}, 5^{\prime}-\mathrm{CH}\right), 8.26\left(1 \mathrm{H}_{\text {arom }}, \mathrm{dd}, J 0.9,8.3 \mathrm{~Hz}, 3^{\prime}-\mathrm{CH}\right) .{ }^{13} \mathrm{C}$ NMR $(75$ $\left.\mathrm{MHz}, \mathrm{CDCl}_{3}\right): \delta_{\mathrm{C}} 13.2\left(4-\mathrm{CH}_{3}\right), 43.9(\mathrm{C}-3), 53.3\left(5-\mathrm{CH}_{2}\right), 57.2(\mathrm{C}-4), 123.9(\mathrm{CH}), 124.2(2 \mathrm{CH})$, $126.6(\mathrm{CH}), 127.3\left(p-\mathrm{CH}_{\mathrm{Ph}}\right), 127.9(\mathrm{CH}), 128.3\left(m-\mathrm{CH}_{\mathrm{Ph}}\right) 128.5\left(o-\mathrm{CH}_{\mathrm{Ph}}\right), 128.8(\mathrm{CH}), 129.3$ $(\mathrm{CH}), 133.4$ (C-5a or C-9a), $134.4(\mathrm{CH}), 135.6\left(\mathrm{C}-1^{\prime}\right), 137.4\left(i-\mathrm{CH}_{\mathrm{Ph}}\right), 141.1$ (C-9a or C-5a), 144.7 (C-2'), 167.4 (1-CO), 172.2 (C-2). Anal. Calcd. for $\mathrm{C}_{24} \mathrm{H}_{21} \mathrm{~N}_{3} \mathrm{O}_{4}$ (415.44): C, 69.39; H, $5.10 ; \mathrm{N}, 10.11 \%$. Found: C, 69.15; H, 4.89; N, 10.38\%.

5-Benzyl-3-methyl-1-(2-nitrobenzoyl)-1,3,4,5-tetrahydro-2H-1,5-benzodiazepin-2-one (2f). Yellow crystals, yield $1.34 \mathrm{~g}(65 \%)$, mp 127-128 ${ }^{\circ} \mathrm{C}$. IR: $v$ 1723, 1698 (CO), 1526, $1346\left(\mathrm{NO}_{2}\right)$ $\mathrm{cm}^{-1} .{ }^{1} \mathrm{H}$ NMR $\left(300 \mathrm{MHz}, \mathrm{CDCl}_{3}\right): \delta_{\mathrm{H}} 0.87\left(3 \mathrm{H}, \mathrm{d}, J 6.1 \mathrm{~Hz}, 4-\mathrm{CH}_{3}\right), 2.73-2.90(1 \mathrm{H}, \mathrm{m}, 3-\mathrm{CH}$ and $1 \mathrm{H}, \mathrm{m}, 4-\mathrm{CH}), 3.06(1 \mathrm{H}, \mathrm{dd}, J 9.6,11.7 \mathrm{~Hz}, 4-\mathrm{CH}), 4.03$ and $4.51(2 \mathrm{H}, \mathrm{ABq}, J 13.6 \mathrm{~Hz}, 5-$ $\left.\mathrm{CH}_{2}\right), 7.22-7.62\left(11 \mathrm{H}_{\text {arom }}, \mathrm{m}, \mathrm{CH}\right), 7.74\left(1 \mathrm{H}_{\text {arom }}, \mathrm{dt}, J 1.2,7.5 \mathrm{~Hz}, 5^{\prime}-\mathrm{CH}\right), 8.28\left(1 \mathrm{H}_{\text {arom }}, \mathrm{dd}, J\right.$ 1.2, $\left.8.3 \mathrm{~Hz}, 3^{\prime}-\mathrm{CH}\right) .{ }^{13} \mathrm{C} \mathrm{NMR}\left(75 \mathrm{MHz}, \mathrm{CDCl}_{3}\right): \delta_{\mathrm{C}} 12.7\left(3-\mathrm{CH}_{3}\right), 38.5(\mathrm{C}-3), 57.5\left(5-\mathrm{CH}_{2}\right), 61.9(\mathrm{C}-$ 4), $120.7(\mathrm{CH}), 124.0(\mathrm{CH}), 124.6(\mathrm{CH}), 126.6(\mathrm{CH}), 127.7\left(p-\mathrm{CH}_{\mathrm{Ph}}\right), 128.6\left(m-\mathrm{CH}_{\mathrm{Ph}}\right) 128.8$ $(\mathrm{CH}), 128.9\left(o-\mathrm{CH}_{\mathrm{Ph}}\right), 129.5(\mathrm{CH}), 129.9(\mathrm{CH}), 131.9(\mathrm{C}-5 \mathrm{a}$ or $\mathrm{C}-9 \mathrm{a}), 134.7(\mathrm{CH}), 136.1\left(\mathrm{C}-1^{\prime}\right)$, $137.7\left(i-\mathrm{CH}_{\mathrm{Ph}}\right), 144.8$ (C-9a or C-5a), 145.1 (C-2'), 167.7 (1-CO), 175.2 (C-2). Anal. Calcd. for $\mathrm{C}_{24} \mathrm{H}_{21} \mathrm{~N}_{3} \mathrm{O}_{4}$ (415.44): C, 69.39; H, 5.10; N, 10.11\%. Found: C, 69.13; H, 4.93; N, $10.35 \%$.

5-Methyl-1-(2-nitrobenzoyl)-1,3,4,5-tetrahydro-2H-1,5-benzodiazepin-2-one (2g). Sandy crystals, yield $0.81 \mathrm{~g}(50 \%)$, mp 154-156 ${ }^{\circ} \mathrm{C}$. IR: $v$ 1717, 1702 (CO), 1526, $1348\left(\mathrm{NO}_{2}\right) \mathrm{cm}^{-1} .{ }^{1} \mathrm{H}$ NMR $\left(300 \mathrm{MHz}, \mathrm{CDCl}_{3}\right): \delta_{\mathrm{H}} 2.32\left(1 \mathrm{H}\right.$, br, 3- $\left.\mathrm{CH}_{2}\right), 2.58\left(1 \mathrm{H}\right.$, br, 3- $\left.\mathrm{CH}_{2}\right), 2.86\left(3 \mathrm{H}, \mathrm{s}, 5-\mathrm{CH}_{3}\right)$, $2.97\left(1 \mathrm{H}\right.$, br, $\left.4-\mathrm{CH}_{2}\right), 3.56\left(1 \mathrm{H}, \mathrm{br}, 4-\mathrm{CH}_{2}\right), 7.19-7.62\left(6 \mathrm{H}_{\text {arom }}, \mathrm{m}, \mathrm{CH}\right), 7.72\left(1 \mathrm{H}_{\text {arom }}, \mathrm{dt}, J 1.2,7.5\right.$ $\left.\mathrm{Hz}, 5^{\prime}-\mathrm{CH}\right), 8.24\left(1 \mathrm{H}_{\text {arom }}, \mathrm{dd}, J 1.0,8.3 \mathrm{~Hz}, 3^{\prime}-\mathrm{CH}\right) .{ }^{13} \mathrm{C} \mathrm{NMR}\left(75 \mathrm{MHz}, \mathrm{CDCl}_{3}\right): \delta_{\mathrm{C}} 36.0(\mathrm{C}-3)$, $40.5\left(5-\mathrm{CH}_{3}\right), 56.4(\mathrm{C}-4), 119.4(\mathrm{CH}), 123.4(\mathrm{CH}), 124.1(\mathrm{CH}), 127.0(\mathrm{CH}), 128.4(\mathrm{CH}), 129.3$ $(\mathrm{CH}), 129.6(\mathrm{CH}), 131.3\left(\mathrm{C}-5 \mathrm{a}\right.$ or C-9a), $134.3(\mathrm{CH}), 135.4\left(\mathrm{C}-1^{\prime}\right), 144.1$ (C-9a or C-5a), 144.6 (C-2'), 167.3 (1-CO), 172.3 (C-2). Anal. Calcd. for $\mathrm{C}_{17} \mathrm{H}_{15} \mathrm{~N}_{3} \mathrm{O}_{4}$ (325.32): C, 62.76; H, 4.65; N, $12.92 \%$. Found: C, 62.52; H, 4.81; N, $13.11 \%$.

4,5-Dimethyl-1-(2-nitrobenzoyl)-1,3,4,5-tetrahydro-2H-1,5-benzodiazepin-2-one

(2h). Yellowish crystals, yield $0.93 \mathrm{~g}$ (55\%), mp 120-122 ${ }^{\circ} \mathrm{C}$. IR: $v$ 1726, 1702 (CO), 1528, 1346 $\left(\mathrm{NO}_{2}\right) \mathrm{cm}^{-1}$. ${ }^{1} \mathrm{H}$ NMR $\left(400 \mathrm{MHz}, \mathrm{CDCl}_{3}\right): \delta_{\mathrm{H}} 0.97\left((0.7) 3 \mathrm{H}, \mathrm{br}, 4-\mathrm{CH}_{3}\right), 1.34((0.3) 3 \mathrm{H}, \mathrm{br}, 4-$ $\left.\mathrm{CH}_{3}\right), 2.05\left((0.3) 2 \mathrm{H}\right.$, br, 3- $\left.\mathrm{CH}_{2}\right), 2.29\left((0.7) 2 \mathrm{H}\right.$, br, 3- $\left.\mathrm{CH}_{2}\right), 2.87\left(3 \mathrm{H}, \mathrm{s}, 5-\mathrm{CH}_{3}\right), 3.15((0.3) 1 \mathrm{H}$, br, 4-CH), $3.80((0.7) 1 \mathrm{H}, \mathrm{br}, 4-\mathrm{CH}), 7.22-7.61\left(6 \mathrm{H}_{\text {arom }}, \mathrm{m}, \mathrm{CH}\right), 7.72\left(1 \mathrm{H}_{\text {arom }}, \mathrm{dt}, J 1.0,7.5 \mathrm{~Hz}\right.$, $\left.5^{\prime}-\mathrm{CH}\right), 8.23\left(1 \mathrm{H}_{\text {arom }}, \mathrm{br}, 3^{\prime}-\mathrm{CH}\right) .{ }^{13} \mathrm{C} \mathrm{NMR}\left(100 \mathrm{MHz}, \mathrm{CDCl}_{3}\right): \delta_{\mathrm{C}} 13.3[19.8]\left(4-\mathrm{CH}_{3}\right), 37.2[38.3]$ $\left(5-\mathrm{CH}_{3}\right),[42.4] 44.0(\mathrm{C}-3), 60.6(\mathrm{C}-4), 119.5^{*}, 122.6^{*}, 122.9^{*}, 123.9^{*}, 124.1(\mathrm{CH}), 127.3$ [126.6] $(\mathrm{CH}), 126.6^{*}, 126.7^{*}, 127.3^{*}, 128.0^{*}, 128.3^{*}, 128.4^{*}, 128.5^{*}, 128.6^{*}, 128.8^{*}, 129.3(\mathrm{CH})$, 129.4*, [131.2]132.6 (C-9a), $134.3(\mathrm{CH}), 135.5$ (C-1'), 141.4[146.0] (C-5a), 144.6 (C-2'), 
[167.1]167.4 (1-CO), [170.7]172.2 (C-2). Values of chemical shift gave in angle brackets correspond to the minor isomer, * marked values are chemical shifts of undefined resonances. Anal. Calcd. for $\mathrm{C}_{18} \mathrm{H}_{17} \mathrm{~N}_{3} \mathrm{O}_{4}$ (339.35): C, 63.71; H, 5.05; N, 12.38\%. Found: C, 63.52; H, 4.88; N, $12.12 \%$.

3,5-Dimethyl-1-(2-nitrobenzoyl)-1,3,4,5-tetrahydro-2H-1,5-benzodiazepin-2-one (2i). Brown crystals, yield $0.85 \mathrm{~g}(50 \%)$, mp 167-169 ${ }^{\circ} \mathrm{C}$. IR: $v$ 1728, 1697 (CO), 1530, $1347\left(\mathrm{NO}_{2}\right) \mathrm{cm}^{-1} .{ }^{1} \mathrm{H}$ NMR $\left(300 \mathrm{MHz}, \mathrm{CDCl}_{3}\right): \delta_{\mathrm{H}} 0.93\left(3 \mathrm{H}, \mathrm{d}, J 6.4 \mathrm{~Hz}, 3-\mathrm{CH}_{3}\right), 2.69-2.82(1 \mathrm{H}, \mathrm{m}, 3-\mathrm{CH}), 2.82(3 \mathrm{H}$, s, 5- $\left.\mathrm{CH}_{3}\right), 2.92\left(1 \mathrm{H}, \mathrm{dd}, J 6.7,9.8 \mathrm{~Hz}, 4-\mathrm{CH}_{2}\right), 3.16\left(1 \mathrm{H}, \mathrm{dd}, J\right.$ 9.8, $\left.12.0 \mathrm{~Hz}, 4-\mathrm{CH}_{2}\right), 7.17-7.61$ $\left(6 \mathrm{H}_{\text {arom }}, \mathrm{m}, \mathrm{CH}\right), 7.73\left(1 \mathrm{H}_{\text {arom }}, \mathrm{dt}, J 1.2,7.5 \mathrm{~Hz}, 5^{\prime}-\mathrm{CH}\right), 8.24\left(1 \mathrm{H}_{\text {arom }}, \mathrm{dd}, J 1.1,8.3 \mathrm{~Hz}, 3^{\prime}-\mathrm{CH}\right)$ ${ }^{13} \mathrm{C} \mathrm{NMR}\left(75 \mathrm{MHz}, \mathrm{CDCl}_{3}\right): \delta_{\mathrm{C}} 12.4\left(3-\mathrm{CH}_{3}\right), 38.2(\mathrm{C}-3), 40.3\left(5-\mathrm{CH}_{3}\right), 64.4(\mathrm{C}-4), 118.9(\mathrm{CH})$, $123.1(\mathrm{CH}), 124.1(\mathrm{CH}), 126.9(\mathrm{CH}), 128.4(\mathrm{CH}), 129.3(\mathrm{CH}), 129.5(\mathrm{CH}), 130.8(\mathrm{C}-5 \mathrm{a}$ or $\mathrm{C}-9 \mathrm{a})$, $134.4(\mathrm{CH}), 135.7\left(\mathrm{C}-1^{\prime}\right), 144.4$ (C-9a or C-5a), 145.1 (C-2'), 167.4 (1-CO), 172.2 (C-2). Anal. Calcd. for $\mathrm{C}_{18} \mathrm{H}_{17} \mathrm{~N}_{3} \mathrm{O}_{4}$ (339.35): C, 63.71; H, 5.05; N, 12.38\%. Found: C, 63.49; H, 5.27; N, $12.55 \%$.

General procedure for the synthesis of $N$-\{3-[(5-benzoyl-4-R $\mathbf{R}^{\mathbf{2}-3-R^{1}-2-0 x 0-2,3,4,5-}$ tetrahydro-1H-1,5-benzodiazepin-1-yl)carbonyl]-4-nitrophenyl \}acetamides 4a-c. A suspension of 5-acetylamino-2-nitrobenzoic acid $(1.45 \mathrm{~g}, 6.5 \mathrm{mmol})$ and thionyl chloride $(7.7 \mathrm{~g}$, $4.7 \mathrm{ml}, 65 \mathrm{mmol})$ in dry chloroform $(50 \mathrm{ml})$ was carefully refluxed until reaction mixture turned clear $(\sim 7 \mathrm{~h})$. The solvent was evaporated under vacuum, then dry benzene $(30 \mathrm{ml})$ was added and distilled out. After repeating this procedure twice, dark oil was dissolved in dry DCE (10 ml) and added dropwise at room temperature to a stirred solution of appropriate benzodiazepine 1a-c (5 mmol) in dry DCE $(60-80 \mathrm{ml})$ containing DIPEA $(1.05 \mathrm{ml}, 6 \mathrm{mmol})$ and catalytic amount of DMAP. The reaction mixture was stirred at room temperature for $24 \mathrm{~h}$ and then filtered with suction. Yellow solid is washed with big amount of cold chloroform and dried.

N-\{3-[(5-Benzoyl-2-oxo-2,3,4,5-tetrahydro-1H-1,5-benzodiazepin-1-yl)carbonyl]-4nitrophenyl \}acetamide (4a). Sandy crystals, yield $0.59 \mathrm{~g}(25 \%)$, mp 268-271 ${ }^{\circ} \mathrm{C}$. IR: $v 3368$ $(\mathrm{NH}), 1730,1711,1655$ (CO), 1500, $1332\left(\mathrm{NO}_{2}\right) \mathrm{cm}^{-1} .{ }^{1} \mathrm{H}$ NMR $\left(300 \mathrm{MHz}, \mathrm{DMSO}-d_{6}\right): \delta_{\mathrm{H}} 2.12$ $\left(3 \mathrm{H}, \mathrm{s}, \mathrm{COCH}_{3}\right), 2.55\left(1 \mathrm{H}, \mathrm{t}, J 5.6 \mathrm{~Hz}, 3-\mathrm{CH}_{2}\right), 2.67\left(1 \mathrm{H}, \mathrm{dt}, J\right.$ 6.5, $\left.13.7 \mathrm{~Hz}, 3-\mathrm{CH}_{2}\right), 3.66(1 \mathrm{H}$, $\mathrm{dd}, J$ 6.4, $\left.13.0 \mathrm{~Hz}, 4-\mathrm{CH}_{2}\right), 4.37\left(1 \mathrm{H}, \mathrm{t}, J 13.1 \mathrm{~Hz}, 4-\mathrm{CH}_{2}\right), 6.94-7.90\left(11 \mathrm{H}_{\text {arom }}, \mathrm{m}, \mathrm{CH}\right), 8.30$ $\left(1 \mathrm{H}_{\text {arom }}, \mathrm{dd}, J 9.2 \mathrm{~Hz}, 3^{\prime}-\mathrm{CH}\right), 10.72\left(1 \mathrm{H}, \mathrm{s}, 5^{\prime}-\mathrm{NH}\right) .{ }^{13} \mathrm{C} \mathrm{NMR}\left(75 \mathrm{MHz}, \mathrm{DMSO}-d_{6}\right): \delta_{\mathrm{C}} 24.3$ $\left(\mathrm{COCH}_{3}\right), 34.6(\mathrm{C}-3), 47.2(\mathrm{C}-4), 115.3(\mathrm{CH}), 118.6(\mathrm{CH}), 126.1(\mathrm{CH}), 127.9\left(o-\mathrm{CH}_{\mathrm{Ph}}\right), 128.1$ $(\mathrm{CH}), 128.7\left(m-\mathrm{CH}_{\mathrm{Ph}}\right), 129.4(\mathrm{C}-5 \mathrm{a}$ or $\mathrm{C}-9 \mathrm{a}), 129.6(\mathrm{CH}), 130.1(\mathrm{CH}), 130.4\left(p-\mathrm{CH}_{\mathrm{Ph}}\right), 133.6(i-$ $\left.\mathrm{CH}_{\mathrm{Ph}}\right), 135.0(\mathrm{CH}), 136.2$ (C-1'), 136.6 (C-9a or C-5a), 137.9 (C-2'), 145.5 (C), 167.1 (1-CO),

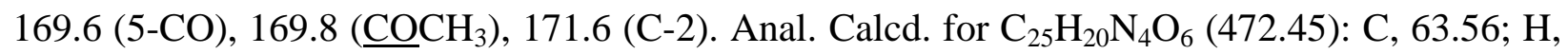
4.27 ; N, 11.86\%. Found: C, 63.32; H, 4.02; N, 12.02\%.

N-\{3-[(5-Benzoyl-4-methyl-2-oxo-2,3,4,5-tetrahydro-1H-1,5-benzodiazepin-1-yl)carbonyl]4-nitrophenyl \}acetamide (4b). Sandy crystals, yield $0.61 \mathrm{~g}(25 \%)$, mp 291-294 ${ }^{\circ} \mathrm{C}$. IR: $v 3383$ $(\mathrm{NH}), 1711,1652$ (CO), 1497, $1336\left(\mathrm{NO}_{2}\right) \mathrm{cm}^{-1} .{ }^{1} \mathrm{H}$ NMR (400 MHz, DMSO- $\left.d_{6}\right): \delta_{\mathrm{H}} 1.13(3 \mathrm{H}$, d, J 5.9 Hz, 4-CH $)_{3}, 2.12\left(3 \mathrm{H}, \mathrm{s}, \mathrm{COCH}_{3}\right), 2.36\left(1 \mathrm{H}, \mathrm{t}, J 12.9 \mathrm{~Hz}, 3-\mathrm{CH}_{2}\right), 2.48-2.55\left(1 \mathrm{H}, 3-\mathrm{CH}_{2}\right.$ overlapped with solvent signal $), 4.93\left(1 \mathrm{H}, \mathrm{br}, 4-\mathrm{CH}_{2}\right), 6.93-7.88\left(11 \mathrm{H}_{\mathrm{arom}}, \mathrm{m}, \mathrm{CH}\right), 8.31\left(1 \mathrm{H}_{\text {arom}}\right.$, 
$\left.\mathrm{d}, J 9.2 \mathrm{~Hz}, 3^{\prime}-\mathrm{CH}\right), 10.71\left(1 \mathrm{H}, \mathrm{s}, 5^{\prime}-\mathrm{NH}\right) .{ }^{13} \mathrm{C}$ NMR $\left(100 \mathrm{MHz}, \mathrm{DMSO}-d_{6}\right): \delta_{\mathrm{C}} 17.5\left(4-\mathrm{CH}_{3}\right)$, $24.2\left(\mathrm{COCH}_{3}\right), 41.8(\mathrm{C}-3), 53.54(\mathrm{C}-4), 115.2(\mathrm{CH}), 118.5(\mathrm{CH}), 126.1(\mathrm{CH}), 127.8\left(o-\mathrm{CH}_{\mathrm{Ph}}\right)$, $128.5\left(m-\mathrm{CH}_{\mathrm{Ph}}\right), 128.5(\mathrm{CH}), 128.8(\mathrm{C}-5 \mathrm{a}$ or $\mathrm{C}-9 \mathrm{a}), 129.3(\mathrm{CH}), 130.1\left(p-\mathrm{CH}_{\mathrm{Ph}}\right), 131.2(\mathrm{CH})$, $134.4\left(i-\mathrm{CH}_{\mathrm{Ph}}\right), 134.4(\mathrm{CH}), 135.1$ (C-9a or C-5a), $136.2\left(\mathrm{C}-1^{\prime}\right), 137.9\left(\mathrm{C}-2^{\prime}\right), 145.4\left(\mathrm{C}-5^{\prime}\right)$, 167.2 (1-CO), 168.8 (5-CO), $169.6\left(\mathrm{COCH}_{3}\right), 171.0(\mathrm{C}-2)$. Anal. Calcd. for $\mathrm{C}_{26} \mathrm{H}_{22} \mathrm{~N}_{4} \mathrm{O}_{6}$ (486.48): C, 64.19; H, 4.56; N, 11.52\%. Found: C, 63.98; H, 4.71; N, $11.33 \%$.

N-\{3-[(5-Benzoyl-3-methyl-2-oxo-2,3,4,5-tetrahydro-1H-1,5-benzodiazepin-1-yl)carbonyl]4-nitrophenyl \}acetamide (4c). Sandy crystals, yield 0.85 g (35\%), mp 297-299 ${ }^{\circ} \mathrm{C}$. IR: $v 3361$ (NH), 1709, 1648 (CO), 1501, $1334\left(\mathrm{NO}_{2}\right) \mathrm{cm}^{-1} .{ }^{1} \mathrm{H}$ NMR $\left(300 \mathrm{MHz}, \mathrm{DMSO}-d_{6}\right): \delta_{\mathrm{H}} 0.93(3 \mathrm{H}$, d, J $\left.6.3 \mathrm{~Hz}, 3-\mathrm{CH}_{3}\right), 2.12\left(3 \mathrm{H}, \mathrm{s}, \mathrm{COCH}_{3}\right), 2.83(1 \mathrm{H}, \mathrm{m}, 3-\mathrm{CH}), 3.64(1 \mathrm{H}, \mathrm{dd}, J$ 6.4, $12.6 \mathrm{~Hz}, 4-$ $\left.\mathrm{CH}_{2}\right), 4.03\left(1 \mathrm{H}, \mathrm{t}, J 12.5 \mathrm{~Hz}, 4-\mathrm{CH}_{2}\right), 6.96-7.86\left(11 \mathrm{H}_{\text {arom }}, \mathrm{m}, \mathrm{CH}\right), 8.31\left(1 \mathrm{H}_{\text {arom }}, \mathrm{d}, J 9.2 \mathrm{~Hz}, 3^{\prime}-\right.$ $\mathrm{CH}), 10.71\left(1 \mathrm{H}, \mathrm{s}, 5^{\prime}-\mathrm{NH}\right) .{ }^{13} \mathrm{C}$ NMR $\left(75 \mathrm{MHz}, \mathrm{DMSO}-d_{6}\right): \delta_{\mathrm{C}} 12.2\left(3-\mathrm{CH}_{3}\right), 24.3\left(\mathrm{COCH}_{3}\right), 37.0$ $(\mathrm{C}-3), 53.9(\mathrm{C}-4), 115.2(\mathrm{CH}), 118.5(\mathrm{CH}), 126.1(\mathrm{CH}), 127.9\left(o-\mathrm{CH}_{\mathrm{Ph}}\right), 128.1(\mathrm{CH}), 128.7(\mathrm{~m}-$ $\left.\mathrm{CH}_{\mathrm{Ph}}\right), 129.1$ (C-5a or C-9a), $129.5(\mathrm{CH}), 129.7(\mathrm{CH}), 130.4\left(p-\mathrm{CH}_{\mathrm{Ph}}\right), 133.1\left(i-\mathrm{CH}_{\mathrm{Ph}}\right), 134.9$ $(\mathrm{CH}), 136.5\left(\mathrm{C}-1^{\prime}\right), 137.3$ (C-2'), 137.8 (C-9a or C-5a), 145.4 (C-5'), 167.3 (1-CO), 169.5 (5$\mathrm{CO}), 169.6\left(\mathrm{COCH}_{3}\right), 174.0(\mathrm{C}-2)$. Anal. Calcd. for $\mathrm{C}_{26} \mathrm{H}_{22} \mathrm{~N}_{4} \mathrm{O}_{6}$ (486.48): C, 64.19; H, 4.56; N, $11.52 \%$. Found: C, 64.39; H, 4.69; N, $11.71 \%$.

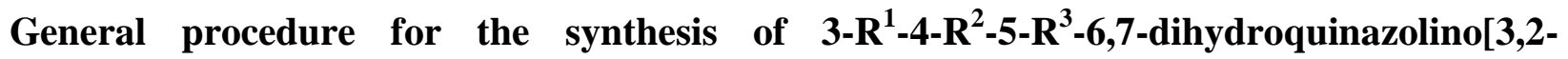
a][1,5]benzodiazepin-13(5H)-ones 3a,3b, 3d, 3e, 3g, 3h. Zn dust (1.63 g, 25 mmol) was added to a solution of appropriate nitrobenzoylamide $\mathbf{2 a - i}(2.5 \mathrm{mmol})$ in glacial acetic acid $(20-30 \mathrm{~mL})$ and the reaction mixture was stirred at room temperature for 2-3 $\mathrm{h}$. After completion of reduction, as observed by TLC monitoring, the reaction mixture was filtered. The filtrate was concentrated to dryness in vacuum. The residue was dissolved in dichloromethane, the solution washed with $5 \% \mathrm{NaHCO}_{3}$ and water, dried and evaporated to dryness in vacuum. Compounds 3a, 3b, 3e, 3h were obtained after the oily residues were subjected to dry column vacuum chromatography (silicagel) using the DCE-ethyl acetate system for gradient elution and recrystallized from dichloromethane-diethyl ether mixture. Compounds $\mathbf{3 d}$ and $\mathbf{3 g}$ after chromatographic purification were obtained as clear oils. They were held in a refrigerator for a long time and solidified. Hexane-diethyl ether mixture was added and solid material was separated by filtration, washed with cold diethyl ether and dried.

The reduction of compounds $\mathbf{2 c}, \mathbf{2} \mathbf{f}$ and $\mathbf{2} \mathbf{i}$ did not occur. Crystallization of the oily reaction residues from dichloromethane-diethyl ether mixture gave unchanged $\mathbf{2 c}(51 \%), \mathbf{2 f}(53 \%)$ and $\mathbf{2 i}$ (50\%). Filtrate was concentrated and starting benzodiazepines 1c (18\%, ethyl acetate), 1f (25\%, benzene) and $1 \mathbf{i}(23 \%$, benzene) were isolated after chromatographic separation of the obtained residues. Mixed samples with authentic compounds did not show depression of the melting point.

5-Benzoyl-6,7-dihydroquinazolino[3,2-a][1,5]benzodiazepin-13(5H)-one $\quad$ (3a). Grayish crystals, yield $0.84 \mathrm{~g}(91 \%), \mathrm{mp} 219-221{ }^{\circ} \mathrm{C}$. IR: $v$ 1691, $1641(\mathrm{CO}), 1609(\mathrm{C}=\mathrm{N}) \mathrm{cm}^{-1} .{ }^{1} \mathrm{H}$ NMR $\left(300 \mathrm{MHz}, \mathrm{CDCl}_{3}\right): \delta_{\mathrm{H}} 2.89\left(1 \mathrm{H}, \mathrm{dt}, J 6.1,13.6 \mathrm{~Hz}, 3-\mathrm{CH}_{2}\right), 3.13(1 \mathrm{H}, \mathrm{dd}, J 4.4,13.9 \mathrm{~Hz}, 3-$ $\left.\mathrm{CH}_{2}\right), 3.81\left(1 \mathrm{H}, \mathrm{dd}, J 6.0,12.8 \mathrm{~Hz}, 4-\mathrm{CH}_{2}\right), 4.76\left(1 \mathrm{H}, \mathrm{dt}, J 5.0,13.4 \mathrm{~Hz}, 4-\mathrm{CH}_{2}\right), 6.84\left(1 \mathrm{H}_{\text {arom }}, \mathrm{d}\right.$, 
$J 7.8 \mathrm{~Hz}, \mathrm{CH}), 7.16-7.29\left(6 \mathrm{H}_{\text {arom }}, \mathrm{m}, \mathrm{CH}\right), 7.39\left(1 \mathrm{H}_{\text {arom }}, \mathrm{t} . J 7.8 \mathrm{~Hz}, \mathrm{CH}\right), 7.53\left(1 \mathrm{H}_{\text {arom }}, \mathrm{t}, J 7.5 \mathrm{~Hz}\right.$, $\mathrm{CH}), 7.63\left(1 \mathrm{H}_{\text {arom }}, \mathrm{d}, J 7.7 \mathrm{~Hz}, \mathrm{CH}\right), 7.73\left(1 \mathrm{H}_{\text {arom }}, \mathrm{d}, J 7.9 \mathrm{~Hz}, \mathrm{CH}\right), 7.82\left(1 \mathrm{H}_{\text {arom }}, \mathrm{t}, J 7.5 \mathrm{~Hz}, \mathrm{CH}\right)$, $8.37\left(1 \mathrm{H}_{\text {arom }}, \mathrm{d}, J 7.8 \mathrm{~Hz}, 6{ }^{\prime}-\mathrm{CH}\right) .{ }^{13} \mathrm{C} \mathrm{NMR}\left(75 \mathrm{MHz}, \mathrm{CDCl}_{3}\right): \delta_{\mathrm{C}} 33.8(\mathrm{C}-3), 49.4(\mathrm{C}-4), 121.1$ $\left(\mathrm{C}-1^{\prime}\right), 127.2(\mathrm{CH}), 127.3(\mathrm{CH}), 127.4(\mathrm{CH}), 128.0\left(o-\mathrm{CH}_{\mathrm{Ph}}\right), 128.8(\mathrm{CH}), 129.1\left(m-\mathrm{CH}_{\mathrm{Ph}}\right), 129.6$ $(\mathrm{CH}), 129.7(\mathrm{CH}), 130.6\left(p-\mathrm{CH}_{\mathrm{Ph}}\right), 133.1\left(i-\mathrm{C}_{\mathrm{Ph}}\right), 134.2(\mathrm{C}-5 \mathrm{a}$ or C-9a), $135.0(\mathrm{CH}), 136.6(\mathrm{C}-9 \mathrm{a}$ or C-5a), 147.1 (C-2'), 154.1 (C-2), 160.9 (1-CO), 170.9 (5-CO). Anal. Calcd. for $\mathrm{C}_{23} \mathrm{H}_{17} \mathrm{~N}_{3} \mathrm{O}_{2}$ (367.40): C, 75.19; H, 4.66; N, 11.44\%. Found: C, 74.95; H, 4.49; N, $11.65 \%$.

5-Benzoyl-6-methyl-6,7-dihydroquinazolino[3,2-a][1,5]benzodiazepin-13(5H)-one

(3b). Yellowish crystals, yield $0.65 \mathrm{~g}(68 \%), \mathrm{mp} 214-216{ }^{\circ} \mathrm{C}$. IR: $v 1686,1649(\mathrm{CO}), 1611(\mathrm{C}=\mathrm{N}) \mathrm{cm}^{-}$ ${ }^{1} .1 \mathrm{H}$ NMR $\left(300 \mathrm{MHz}, \mathrm{CDCl}_{3}\right): \delta_{\mathrm{H}} 1.34\left(3 \mathrm{H}, \mathrm{d}, J 6.2 \mathrm{~Hz}, 4-\mathrm{CH}_{3}\right), 2.56(1 \mathrm{H}, \mathrm{dd}, J 12.7,13.4 \mathrm{~Hz}$, 3- $\left.\mathrm{CH}_{2}\right), 3.09\left(1 \mathrm{H}, \mathrm{dd}, J 5.0,13.8 \mathrm{~Hz}, 3-\mathrm{CH}_{2}\right), 5.19-5.31(1 \mathrm{H}, 4-\mathrm{CH}), 6.81\left(1 \mathrm{H}_{\text {arom }}, \mathrm{d}, J 7.5 \mathrm{~Hz}\right.$, $\mathrm{CH}), 7.13-7.25\left(6 \mathrm{H}_{\text {arom }}, \mathrm{m}, \mathrm{CH}\right), 7.41\left(1 \mathrm{H}_{\text {arom }}\right.$, dt. $\left.J 1.2,8.1 \mathrm{~Hz}, \mathrm{CH}\right), 7.53\left(1 \mathrm{H}_{\text {arom }}, \mathrm{dd}, J 1.1,15.0\right.$ $\mathrm{Hz}, \mathrm{CH}), 7.72\left(1 \mathrm{H}_{\text {arom }}, \mathrm{d}, J 7.6 \mathrm{~Hz}, \mathrm{CH}\right), 7.82\left(1 \mathrm{H}_{\text {arom }}, \mathrm{dt}, J 1.5,8.3 \mathrm{~Hz}, \mathrm{CH}\right), 8.36\left(1 \mathrm{H}_{\text {arom }}, \mathrm{dd}, J\right.$ 1.2, $\left.8.0 \mathrm{~Hz}, 6^{\prime}-\mathrm{CH}\right) .{ }^{13} \mathrm{C} \mathrm{NMR}\left(75 \mathrm{MHz}, \mathrm{CDCl}_{3}\right): \delta_{\mathrm{C}} 17.9\left(4-\mathrm{CH}_{3}\right), 41.5(\mathrm{C}-3), 55.7(\mathrm{C}-4), 121.1$ $\left(\mathrm{C}-1^{\prime}\right), 127.2(\mathrm{CH}), 127.3(\mathrm{CH}), 127.4(\mathrm{CH}), 127.9\left(o-\mathrm{CH}_{\mathrm{Ph}}\right), 128.2(\mathrm{CH}), 128.7(\mathrm{CH}), 128.7(m-$ $\left.\mathrm{CH}_{\mathrm{Ph}}\right), 129.3(\mathrm{CH}), 130.3\left(p-\mathrm{CH}_{\mathrm{Ph}}\right), 131.0(\mathrm{CH}), 133.8\left(i-\mathrm{C}_{\mathrm{Ph}}\right), 134.6(\mathrm{C}-5 \mathrm{a}$ or $\mathrm{C}-9 \mathrm{a}), 135.0(\mathrm{CH})$, 147.0 (C-2'), 153.8 (C-2), 160.8 (1-CO), 169.8 (5-CO). Anal. Calcd. for $\mathrm{C}_{24} \mathrm{H}_{19} \mathrm{~N}_{3} \mathrm{O}_{2}$ (381.43): C, 75.57; H, 5.02; N, 11.02\%. Found: C, 75.32; H, 4.81; N, $11.27 \%$.

5-Benzyl-6,7-dihydroquinazolino[3,2-a][1,5]benzodiazepin-13(5H)-one (3d). Grayish solid, yield $0.27 \mathrm{~g}(30 \%), \mathrm{mp} 70-73{ }^{\circ} \mathrm{C}$. IR: $v 1686(\mathrm{CO}), 1610(\mathrm{C}=\mathrm{N}) \mathrm{cm}^{-1}$. ${ }^{1} \mathrm{H}$ NMR $(300 \mathrm{MHz}$, $\left.\mathrm{CDCl}_{3}\right): \delta_{\mathrm{H}} 2.79-2.90\left(1 \mathrm{H}, \mathrm{m}, 3-\mathrm{CH}_{2}\right), 2.96-3.07\left(1 \mathrm{H}, \mathrm{m}, 3-\mathrm{CH}_{2}\right.$ and $\left.1 \mathrm{H}, \mathrm{m}, 4-\mathrm{CH}_{2}\right), 3.60-3.69$ $\left(1 \mathrm{H}, \mathrm{m}, 4-\mathrm{CH}_{2}\right), 4.08$ and $4.44\left(2 \mathrm{H}, \mathrm{ABq}, J 13.7 \mathrm{~Hz}, 5-\mathrm{CH}_{2}\right), 7.13-7.85\left(12 \mathrm{H}_{\text {arom }}, \mathrm{m}, \mathrm{CH}\right), 8.37$ $\left(1 \mathrm{H}_{\text {arom }}, \mathrm{dd}, J 1.4,8.0 \mathrm{~Hz}, 66^{\prime}-\mathrm{CH}\right){ }^{13} \mathrm{C} \mathrm{NMR}\left(75 \mathrm{MHz}, \mathrm{CDCl}_{3}\right): \delta_{\mathrm{C}} 34.6(\mathrm{C}-3), 56.2(\mathrm{C}-4), 57.0$ $\left(5-\mathrm{CH}_{2}\right), 120.9(\mathrm{CH}), 121.1\left(\mathrm{C}-1^{\prime}\right), 123.4(\mathrm{CH}), 126.5(\mathrm{CH}), 126.8(\mathrm{CH}), 127.2(\mathrm{CH}), 127.5(p-$ $\left.\mathrm{CH}_{\mathrm{Ph}}\right), 128.0\left(o-\mathrm{CH}_{\mathrm{Ph}}\right), 128.1(\mathrm{CH}), 128.5\left(m-\mathrm{CH}_{\mathrm{Ph}}\right), 129.8(\mathrm{CH}), 130.8(\mathrm{C}-5 \mathrm{a}$ or C-9a), 134.6 $(\mathrm{CH}), 137.3$ ( $\left.i-\mathrm{C}_{\mathrm{Ph}}\right), 143.7$ (C-9a or C-5a), 146.5 (C-2'), 156.3 (C-2), 160.6 (1-CO). Anal. Calcd. for $\mathrm{C}_{23} \mathrm{H}_{19} \mathrm{~N}_{3} \mathrm{O}$ (353.42): C, 78.16; H, 5.42; N, 11.89\%. Found: C, 78.47; H, 5.61; N, $11.63 \%$.

5-Benzyl-6-methyl-6,7-dihydroquinazolino[3,2-a][1,5]benzodiazepin-13(5H)-one (3e). Sandy crystals, yield $0.73 \mathrm{~g}(80 \%)$, mp 183-185 ${ }^{\circ} \mathrm{C}$. IR: $v 1682(\mathrm{CO}), 1609(\mathrm{C}=\mathrm{N}) \mathrm{cm}^{-1} .{ }^{1} \mathrm{H}$ NMR $(300$ $\left.\mathrm{MHz}, \mathrm{CDCl}_{3}\right): \delta_{\mathrm{H}} 1.08\left(3 \mathrm{H}, \mathrm{d}, J 6.1 \mathrm{~Hz}, 4-\mathrm{CH}_{3}\right), 2.48\left(1 \mathrm{H}, \mathrm{dd}, J 1.1,13.1 \mathrm{~Hz}, 3-\mathrm{CH}_{2}\right), 2.93(1 \mathrm{H}$, $\left.\mathrm{dd}, J 5.6,13.4 \mathrm{~Hz}, 3-\mathrm{CH}_{2}\right), 3.92\left(1 \mathrm{H}, \mathrm{tt}, J 5.9,11.7 \mathrm{~Hz}, 4-\mathrm{CH}_{2}\right), 4.24$ and $4.35(2 \mathrm{H}, \mathrm{ABq}, J 14.1$ $\left.\mathrm{Hz}, 5-\mathrm{CH}_{2}\right), 7.05-7.84\left(12 \mathrm{H}_{\text {arom }}, \mathrm{m}, \mathrm{CH}\right), 8.39\left(1 \mathrm{H}_{\text {arom }}, \mathrm{d}, J 7.9 \mathrm{~Hz}, 6^{\prime}-\mathrm{CH}\right){ }^{13} \mathrm{C} \mathrm{NMR}(75 \mathrm{MHz}$, $\left.\mathrm{CDCl}_{3}\right): \delta_{\mathrm{C}} 13.4\left(4-\mathrm{CH}_{3}\right), 42.9(\mathrm{C}-3), 53.3\left(5-\mathrm{CH}_{2}\right), 59.0(\mathrm{C}-4), 121.0\left(\mathrm{C}-1^{\prime}\right), 123.6(\mathrm{CH}), 123.8$ $(\mathrm{CH}), 126.6(\mathrm{CH}), 126.7(\mathrm{CH}), 127.1(\mathrm{CH}), 127.4\left(p-\mathrm{CH}_{\mathrm{Ph}}\right), 127.8\left(m-\mathrm{CH}_{\mathrm{Ph}}\right), 127.9(\mathrm{CH}), 128.3$ $\left(o-\mathrm{CH}_{\mathrm{Ph}}\right), 129.0(\mathrm{CH}), 132.2(\mathrm{C}-5 \mathrm{a}$ or $\mathrm{C}-9 \mathrm{a}), 134.5(\mathrm{CH}), 137.3\left(i-\mathrm{C}_{\mathrm{Ph}}\right), 140.8$ (C-5a or C-9a), 147.0 (C-2'), 155.9 (C-2), 160.7 (1-CO). Anal. Calcd. for $\mathrm{C}_{24} \mathrm{H}_{21} \mathrm{~N}_{3} \mathrm{O}$ (367.44): C, 78.45; H, 5.76; $\mathrm{N}, 11.44 \%$. Found: C, 78.66; H, 5.92; N, 11.17\%.

5-Methyl-6,7-dihydroquinazolino[3,2-a][1,5]benzodiazepin-13(5H)-one (3g). Sandy solid,

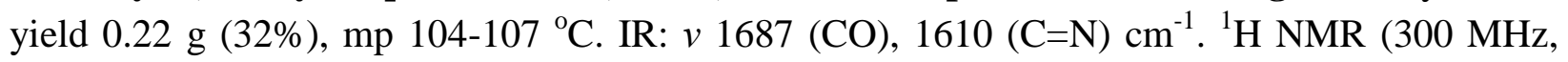
$\left.\mathrm{CDCl}_{3}\right): \delta_{\mathrm{H}} 2.76\left(3 \mathrm{H}, \mathrm{s}, 5-\mathrm{CH}_{3}\right), 2.82\left(1 \mathrm{H}, \mathrm{dd}, J\right.$ 7.0, $\left.12.9 \mathrm{~Hz}, 3-\mathrm{CH}_{2}\right), 2.99(1 \mathrm{H}, \mathrm{dd}, J 5.7,13.3$ 
$\left.\mathrm{Hz}, 3-\mathrm{CH}_{2}\right), 3.06\left(1 \mathrm{H}\right.$, ddd, $J$ 0.7, 6.8, $\left.9.8 \mathrm{~Hz}, 4-\mathrm{CH}_{2}\right), 3.68\left(1 \mathrm{H}\right.$, ddd, J 5.4, 9.8, $\left.12.7 \mathrm{~Hz}, 4-\mathrm{CH}_{2}\right)$, 7.18-7.81 $\left(7 \mathrm{H}_{\text {arom }}, \mathrm{m}, \mathrm{CH}\right), 8.31\left(1 \mathrm{H}_{\text {arom }}, \mathrm{d}, J 8.2 \mathrm{~Hz}, 66^{\prime}-\mathrm{CH}\right) .{ }^{13} \mathrm{C} \mathrm{NMR}\left(75 \mathrm{MHz}, \mathrm{CDCl}_{3}\right): \delta_{\mathrm{C}}$ $34.7(\mathrm{C}-3), 40.4\left(5-\mathrm{CH}_{3}\right), 58.8(\mathrm{C}-4), 119.5(\mathrm{CH}), 121.2\left(\mathrm{C}-1^{\prime}\right), 122.8(\mathrm{CH}), 126.4(\mathrm{CH}), 126.8$ $(\mathrm{CH}), 127.4(\mathrm{CH}), 128.2(\mathrm{CH}), 129.8(\mathrm{CH}), 129.8(\mathrm{C}-5 \mathrm{a}$ or C-9a), $134.6(\mathrm{CH}), 144.1(\mathrm{C}-9 \mathrm{a}$ or C5a), 146.5 (C-2'), 156.2 (C-2), 160.7 (1-CO). Anal. Calcd. for $\mathrm{C}_{17} \mathrm{H}_{15} \mathrm{~N}_{3} \mathrm{O}$ (277.32): C, 73.63; H, $5.45 ; \mathrm{N}, 15.15 \%$. Found: C, 73.94; H, 5.68; N, $11.41 \%$.

5,6-Dimethyl-6,7-dihydroquinazolino[3,2-a][1,5]benzodiazepin-13(5H)-one (3h). Yellowish solid, yield $0.58 \mathrm{~g}(80 \%)$, mp 57-60 ${ }^{\circ} \mathrm{C}$. IR: $v 1687(\mathrm{CO}), 1610(\mathrm{C}=\mathrm{N}) \mathrm{cm}^{-1} .{ }^{1} \mathrm{H}$ NMR $(400 \mathrm{MHz}$, $\left.\mathrm{CDCl}_{3}\right): \delta_{\mathrm{H}} 1.05\left((0.8) 3 \mathrm{H}, \mathrm{d}, J 6.1 \mathrm{~Hz}, 4-\mathrm{CH}_{3}\right), 1.45\left((0.2) 3 \mathrm{H}, \mathrm{d}, J 6.1 \mathrm{~Hz}, 4-\mathrm{CH}_{3}\right), 2.47(1 \mathrm{H}, \mathrm{dd}$, $J$ 11.6, $\left.13.5 \mathrm{~Hz}, 3-\mathrm{CH}_{2}\right), 2.77\left((0.8) 3 \mathrm{H}, \mathrm{s}, 5-\mathrm{CH}_{3}\right), 2.79\left((0.2) 3 \mathrm{H}, \mathrm{s}, 5-\mathrm{CH}_{3}\right), 2.96((0.2) 1 \mathrm{H}, \mathrm{dd}, J$ 6.3, $\left.13.6 \mathrm{~Hz}, 3-\mathrm{CH}_{2}\right), 3.03\left((0.8) 1 \mathrm{H}, \mathrm{dd}, J 5.5,13.5 \mathrm{~Hz}, 3-\mathrm{CH}_{2}\right), 3.25((0.2) 1 \mathrm{H}, \mathrm{dp}, J 1.3,6.3 \mathrm{~Hz}$, 4-CH), $3.94((0.8) 1 \mathrm{H}, \mathrm{pd}, J$ 6,0, $11.8 \mathrm{~Hz}, 4-\mathrm{CH}), 7.16-7.81\left(7 \mathrm{H}_{\text {arom }}, \mathrm{m}, \mathrm{CH}\right), 8.31\left(1 \mathrm{H}_{\text {arom }}, \mathrm{d}, J 8.2\right.$ $\left.\mathrm{Hz}, 6{ }^{\prime}-\mathrm{CH}\right) .{ }^{13} \mathrm{C} \mathrm{NMR}\left(100 \mathrm{MHz}, \mathrm{CDCl}_{3}\right): \delta_{\mathrm{C}} 13.4[19.5]\left(4-\mathrm{CH}_{3}\right), 37.3[38.3]\left(5-\mathrm{CH}_{3}\right),[41.0] 42.9$ (C-3), 62.4[62.8] (C-4), [120.0]121.2 (C-1'), 122.5[122.8] (CH), $123.0(\mathrm{CH}), 126.4(\mathrm{CH}), 126.7$ $(\mathrm{CH}),[127.3] 127.4(\mathrm{CH}),[127.8] 128.0(\mathrm{CH}), 129.1[129.5](\mathrm{CH}), 130.8(\mathrm{C}-\mathrm{C} 5 \mathrm{a}$ or C-9a), 134.5 $(\mathrm{CH}), 141.6$ (C-9a or C-5a), [146.2]146.5 (C-2'), [154.1]156.0 (C-2), [159.0]160.7 (1-CO). Values of chemical shift gave in angle brackets correspond to the minor isomer. Anal. Calcd. for $\mathrm{C}_{18} \mathrm{H}_{17} \mathrm{~N}_{3} \mathrm{O}$ (291.35): C, 72.20; H, 5.88; N, 14.42\%. Found: C, 71.95; H, 6.09; N, 14.15\%.

5-Benzoyl-1,3,4,5-tetrahydro-2H-1,5-benzodiazepin-2-one (1a). Compound $1 \mathrm{a}$ was synthesized according to procedure ${ }^{17}$ from $3.2 \mathrm{~g}(20 \mathrm{mmol})$ of 1,3,4,5-tetrahydro- $2 \mathrm{H}-1,5$ benzodiazepin-2-one and $2.55 \mathrm{ml}(22 \mathrm{mmol})$ of benzoyl chloride, and $1.78 \mathrm{ml}(22 \mathrm{mmol})$ of pyridine. Yield $4.6 \mathrm{~g}$ (86\%) 1a, white crystals, mp 198-200 ${ }^{\circ} \mathrm{C}$ (from ethyl acetate). IR: $v$ 3204, 3153, $3104(\mathrm{NH}), 1682,1627(\mathrm{CO}) .{ }^{1} \mathrm{H}$ NMR (300 MHz, $\left.\mathrm{CDCl}_{3}\right): \delta_{\mathrm{H}} 2.68\left(1 \mathrm{H}, \mathrm{br}, 3-\mathrm{CH}_{2}\right), 2.88$ $\left(1 \mathrm{H}, \mathrm{br}, 3-\mathrm{CH}_{2}\right), 3.88\left(1 \mathrm{H}, \mathrm{br}, 4-\mathrm{CH}_{2}\right), 4.87\left(1 \mathrm{H}, \mathrm{br}, 4-\mathrm{CH}_{2}\right), 6.72\left(1 \mathrm{H}_{\text {arom }}, \mathrm{d}, J 7.8 \mathrm{~Hz}, \mathrm{CH}\right), 6.82-$ $7.24\left(8 \mathrm{H}_{\text {arom }}, \mathrm{m}, \mathrm{CH}\right), 9.44(1 \mathrm{H}, \mathrm{s}, \mathrm{NH}) .{ }^{13} \mathrm{C} \mathrm{NMR}\left(75 \mathrm{MHz}, \mathrm{CDCl}_{3}\right): \delta_{\mathrm{C}} 33.0(\mathrm{C}-3), 49.0(\mathrm{C}-4)$, 122.3 (C-9), 125.8 (C-7), $127.9\left(o-\mathrm{CH}_{\mathrm{Ph}}\right), 128.2\left(m-\mathrm{CH}_{\mathrm{Ph}}\right), 128.4(\mathrm{C}-6), 130.2\left(\mathrm{C}-8\right.$ or $\left.p-\mathrm{CH}_{\mathrm{Ph}}\right)$, $130.3\left(p-\mathrm{CH}_{\mathrm{Ph}}\right.$ or C-8), 134.5 ( $i-\mathrm{C}_{\mathrm{Ph}}$ or C-9a or C-5a ), 135.0 (C-5a or C-9a or $\left.i-\mathrm{C}_{\mathrm{Ph}}\right), 135.0(\mathrm{C}-9 \mathrm{a}$ or C-5a or $i-\mathrm{C}_{\mathrm{Ph}}$ ), 171.0 (5-CO), 174.1 (C-2). Anal. Calcd. for $\mathrm{C}_{16} \mathrm{H}_{14} \mathrm{~N}_{2} \mathrm{O}_{2}$ (266.30): C, 72.16; $\mathrm{H}$, $5.30 ; \mathrm{N}, 10.52 \%$. Found: C, 72.41; H, 5.47; N, 10.71\%.

5-Benzoyl-4-methyl-1,3,4,5-tetrahydro-2H-1,5-benzodiazepin-2-one (1b). Compound $1 \mathrm{~b}$ was synthesized analogously as $1 \mathrm{a}$ from $3.6 \mathrm{~g}(20 \mathrm{mmol})$ of 4-methyl-1,3,4,5-tetrahydro-2H-1,5benzodiazepin-2-one. ${ }^{17}$ Yield $4.5 \mathrm{~g}(81 \%)$ 1b, white crystals, mp 212-214 ${ }^{\circ} \mathrm{C}$ (from ethyl acetate). IR: v 3178, $3068(\mathrm{NH}), 1686,1646(\mathrm{CO}) .{ }^{1} \mathrm{H}$ NMR $\left(300 \mathrm{MHz}, \mathrm{CDCl}_{3}\right): \delta_{\mathrm{H}} 1.34(3 \mathrm{H}, \mathrm{d}$, $\left.J 6.2 \mathrm{~Hz}, 4-\mathrm{CH}_{3}\right), 2.44-2.61\left(2 \mathrm{H}, \mathrm{m}, 3-\mathrm{CH}_{2}\right), 5.36(1 \mathrm{H}, \mathrm{m}, 4-\mathrm{CH}), 6.71\left(1 \mathrm{H}_{\text {arom }}, \mathrm{d}, J 7.7 \mathrm{~Hz}, \mathrm{CH}\right)$, $6.87\left(1 \mathrm{H}_{\text {arom }}, \mathrm{t}, J 7.5 \mathrm{~Hz}, \mathrm{CH}\right), 7.07-7.24\left(7 \mathrm{H}_{\text {arom }}, \mathrm{m}, \mathrm{CH}\right), 9.11(1 \mathrm{H}, \mathrm{s}, \mathrm{NH}) .{ }^{13} \mathrm{C} \mathrm{NMR}(75 \mathrm{MHz}$, $\left.\mathrm{CDCl}_{3}\right): \delta_{\mathrm{C}} 18.8\left(4-\mathrm{CH}_{3}\right), 40.6(\mathrm{C}-3), 55.7(\mathrm{C}-4), 122.3(\mathrm{C}-9), 126.0(\mathrm{C} 7), 127.8\left(\right.$ o,m- $\left.\mathrm{CH}_{\mathrm{Ph}}\right)$, 128.8 (C-6), 129.9 (C-8), 131.7 ( $\left.p-\mathrm{CH}_{\mathrm{Ph}}\right), 132.9\left(i-\mathrm{C}_{\mathrm{Ph}}\right), 135.5$ (C-9a or C-5a), 136.0 (C-5a or C9a), 170.2 (5-CO), 173.6 (C-2). Anal. Calcd. for $\mathrm{C}_{17} \mathrm{H}_{16} \mathrm{~N}_{2} \mathrm{O}_{2}$ (280.32): C, 72.84; H, 5.75; N, 9.99\%. Found: C, 72.51; H, 5.87; N, 9.71\%. 
5-Benzoyl-3-methyl-1,3,4,5-tetrahydro-2H-1,5-benzodiazepin-2-one (1c). Compound 1c was synthesized analogously as $1 \mathbf{a}$ from $3.6 \mathrm{~g}$ (20 mmol) of 3-methyl-1,3,4,5-tetrahydro-2H-1,5benzodiazepin-2-one. ${ }^{17}$ Yield $4.2 \mathrm{~g}(75 \%)$ 1c, white crystals, mp 171-173 ${ }^{\circ} \mathrm{C}$ (from ethyl acetate). IR: $v$ 3196, $3060(\mathrm{NH}), 1681,1642(\mathrm{CO}) .{ }^{1} \mathrm{H}$ NMR $\left(300 \mathrm{MHz}, \mathrm{CDCl}_{3}\right): \delta_{\mathrm{H}} 1.24(3 \mathrm{H}, \mathrm{d}, J 7.1 \mathrm{~Hz}$, 3- $\left.\mathrm{CH}_{3}\right), 2.92(1 \mathrm{H}, \mathrm{m}, 3-\mathrm{CH}), 3.87\left(1 \mathrm{H}, \mathrm{dd}, J\right.$ 5.8, $\left.12.8 \mathrm{~Hz}, 4-\mathrm{CH}_{2}\right), 4.48(1 \mathrm{H}, \mathrm{t}, J 12.8 \mathrm{~Hz}, 4-$ $\left.\mathrm{CH}_{2}\right), 6.71\left(1 \mathrm{H}_{\text {arom }}, \mathrm{d}, J 7.6 \mathrm{~Hz}, \mathrm{CH}\right), 6.86\left(1 \mathrm{H}_{\text {arom }}, \mathrm{t}, J 7.2 \mathrm{~Hz}, \mathrm{CH}\right), 7.10-7.24\left(7 \mathrm{H}_{\text {arom }}, \mathrm{m}, \mathrm{CH}\right)$, $8.78(1 \mathrm{H}, \mathrm{s}, \mathrm{NH}) .{ }^{13} \mathrm{C} \mathrm{NMR}\left(75 \mathrm{MHz}, \mathrm{CDCl}_{3}\right): \delta_{\mathrm{C}} 12.8\left(3-\mathrm{CH}_{3}\right), 34.9(\mathrm{C}-3), 56.7(\mathrm{C}-4), 122.5$ (C-9), 126.0 (C-7), $127.9\left(o-\mathrm{CH}_{\mathrm{Ph}}\right), 128.2\left(m-\mathrm{CH}_{\mathrm{Ph}}\right), 128.4(\mathrm{C} 6), 130.2\left(p-\mathrm{CH}_{\mathrm{Ph}}\right), 130.2(\mathrm{C}-8)$, 132.9 ( $\left.i-\mathrm{C}_{\mathrm{Ph}}\right), 135.1$ (C-9a or C-5a), 135.3 (C-5a or C-9a), 171.0 (5-CO), 175.7 (C-2). Anal. Calcd. for $\mathrm{C}_{17} \mathrm{H}_{16} \mathrm{~N}_{2} \mathrm{O}_{2}$ (280.32): C, 72.84; H 5.75; N, 9.99\%. Found: C, 73.01; H, 5.61; N, $9.83 \%$.

\section{References}

1. Mhaske, S. B.; Argade, N. P. Tetrahedron 2006, 62, 9787. http://dx.doi.org/10.1016/j.tet.2006.07.098

2. Zhichkin, P.; Kesicki, E.; Treiberg, J.; Bourdou, L.; Ronsheim, M.; Ooi, H. Ch.; White, S.; Judkins, A.; Favifax, D. Org. Lett. 2007, 9, 1415. http://dx.doi.org/10.1021/ol070276c PMid:17348669

3. Dallavalle, S.; Merlini, L.; Beretta, G. L.; Tinelli, S.; Zunino, F. Bioorg. Med. Chem. Lett. 2004, 14, 5757.

http://dx.doi.org/10.1016/j.bmcl.2004.09.039 PMid:15501036

4. Taher, D.; Ishtaiwi, Z. N.; Al-Said, N. H. Arkivoc 2008, (xvi), 154. http://dx.doi.org/10.3998/ark.5550190.0009.g15

5. Al-Said, N. H.; Al-Qaisi, L. S. Tetrahedron Lett. 2006, 47, 693. http://dx.doi.org/10.1016/j.tetlet.2005.11.123

6. Zhang, W.; Williams, J. P.; Lu, Y.; Nagashima, T.; Chu, Q. Tetrahedron Lett. 2007, 48, 563. http://dx.doi.org/10.1016/j.tetlet.2006.11.127 PMid:17479166 PMCid:1865100

7. Al-Said, N. H.; Shawakfeh, K. Q.; Ibrahim, M. I.; Tayyem, S. H. Arkivoc 2010, (ix), 282. http://dx.doi.org/10.3998/ark.5550190.0011.926

8. Janciene, R.; Stumbreviciute, Z.; Podeniene, D.; Puodziunaite, B. D.; Black, S.; Husbands, S. M. J. Heterocyclic Chem. 2006, 43, 979. http://dx.doi.org/10.1002/jhet.5570430424

9. Kosychova, L.; Pleckaitiene, L.; Staniulyte, Z.; Janciene, R.; Palaima, A; Puodziunaite, B. D. Arkivoc 2006, (xiii), 158. http://dx.doi.org/10.3998/ark.5550190.0007.d16

10. Kosychova, L.; Stumbreviciute, Z.; Janciene, R.; Staniulyte, Z.; Puodziunaite, B. D. Arkivoc 2011, (xi), 82. http://dx.doi.org/10.3998/ark.5550190.0012.b08 
11. Lu, Y.; Nagashima, T.; Miriyala, B.; Coude, J.; Khang, W. J. Comb. Chem. 2010, 12, 125. http://dx.doi.org/10.1021/cc9001636 PMid:20000772

12. Dallavalle, S.; Merlini, L. Tetrahedron Lett. 2002, 43, 1835. http://dx.doi.org/10.1016/S0040-4039(02)00140-5

13. Grossi, G.; Di Braccio, M.; Roma, G.; Ballabeni, V.; Tognalini, M.; Calcina, F.; Barocelli, E. Eur. J. Med. Chem. 2002, 37, 933. http://dx.doi.org/10.1016/S0223-5234(02)01400-9

14. Di Braccio, M.; Grossi, G.; Ceruti, M.; Rocco, F.; Loddo, R.; Sanna, G.; Busonera, B.; Murreddu, M.; Marongiu, M. E. Il Farmaco 2005, 60, 113. http://dx.doi.org/10.1016/j.farmac.2004.12.005 PMid:15752470

15. Колодкин, Н. И.; Глибин, Е. Н.; Гинзбург, О. Ф. Ж. Орг.Хим. 1982, XVIII, 1281.

16. Janciene, R. Chem. Heterocycl. Comp. 2011, 47, 390. http://dx.doi.org/10.1007/s10593-011-0772-6

17. Puodzhunaite, B. A.; Yanchiene, R. A.; Talaikite, Z. A.; Zaks, A. C.; Rabotnikov, Yu. M.; Uzachev, E. A. Khim-Farm Zh. 1985, 19, 1195; Chem Abstr 1986, 105, 133861g.

18. Puodžiūnaitè, B.; Kosychova, L.; Jančienè, R., Stumbrevičiūtè, Z. Monatsh. Chem. 1997, $128,1275$. http://dx.doi.org/10.1007/BF00807260

19. Vektariene, A.; Vektaris, G.; Rankin, D. W. H. Heteroatom Chem. 2007, 18, 695. http://dx.doi.org/10.1002/hc.20378

20. Janciene, R.; Stumbreviciute, Z.; Vektariene, A.; Kosychova, L.; Sirutkaitis, R.; Palaima, A.; Staniulyte, Z.; Puodziunaite, B. D. Heteroatom Chem. 2008, 19, 72. http://dx.doi.org/10.1002/hc.20414

21. Raju, B.; Ragul, R.; Sivasankar B. N. Ind. J. Chem. 2009, 48B, 1315.

22. Burge, H. D.; Kollins, D. J.; Davis B. H. Ind. End. Chem. Prod. Res. Dev. 1980, 19, 389. http://dx.doi.org/10.1021/i360075a019

23. De Proft, F.; Van Alsenoy, C.; Peeters, A.; Langenaeker, W.; Geerlings P. J. Comput. Chem. 2002, 23, 1198 . http://dx.doi.org/10.1002/jcc.10067 PMid:12116389

24. Karelson, M.; Lobanov, V. S.; Katritzky, A. R. Chem. Rev. 1996, 96, 1027. http://dx.doi.org/10.1021/cr950202r PMid:11848779

25. Ehresmann, B.; Martin, B.; Horn, A. H. C.; Clark, T. J. Mol. Model. 2003, 9, 342. http://dx.doi.org/10.1007/s00894-003-0153-x PMid:14517613

26. Chirlian, L. E.; Francl, M. M. J. Comput. Chem. 1987, 8, 894. http://dx.doi.org/10.1002/jcc.540080616

27. Vektariene, A.; Vektaris, G.; Svoboda, J. Arkivoc 2009, (vii), 311. http://dx.doi.org/10.3998/ark.5550190.0010.730

28. Vektariene, A.; Vektaris, G. Arkivoc 2006, (xvi), 23. http://dx.doi.org/10.3998/ark.5550190.0007.g03 
29. Janciene, R.; Vektariene, A.; Stumbreviciute, Z.; Puodziunaite, B. Monatsh. Chem. 2011, $142,609$. http://dx.doi.org/10.1007/s00706-011-0496-4

30. Spartan'06, Wavefunction Inc, Irvine, CA. In: Shao, Y.; Molnar, L. F.; Jung, Y.; Kussmann, J.; Ochsenfeld, C.; Brown, S. T.; Gilbert, A. T. B.; Slipchenko, L. V.; Levchenko, S. V.; O'Neill, D. P.; DiStasio, Jr. R. A.; Lochan, R. C.; Wang, T.; Beran, G. J. O.; Besley, N. A.; Herbert, J. M.; Lin, C. Y.; Van Voorhis, T.; Chien, S. H.; Sodt, A.; Steele, R. P.; Rassolov, V. A.; Maslen, P. E.; Korambath, P. P.; Adamson, R. D.; Austin, B.; Baker, J.; Byrd, E. F. C.; Dachsel, H.; Doerksen, R. J.; Dreuw, A.; Dunietz, B. D.; Dutoi, A. D.; Furlani, T. R.; Gwaltney, S. R.; Heyden, A.; Hirata, S.; Hsu, C. P.; Kedziora, G.; Khalliulin, R. Z.; Klunzinger, P.; Lee, A. M.; Lee, M. S.; Liang, W. Z.; Lotan, I.; Nair, N.; Peters, B.; Proynov, E. I.; Pieniazek, P. A.; Rhee, Y. M.; Ritchie, J.; Rosta, E.; Sherrill, C. D.; Simmonett, A. C.; Subotnik, J. E.; Woodcock, H. L.; Zhang, W.; Bell, A. T.; Chakraborty, A. K.; Chipman, D. M.; Keil, F. J.; Warshel, A.; Hehre, W. J.; Schaefer, H. F.; Kong, J.; Krylov, A. I.; Gill, P. M. W.; Head-Gordon, M. Phys. Chem. Chem. Phys. 2006, 8, 3172.

http://dx.doi.org/10.1039/b517914a PMid:16902710

31. Vektariene, A.; Vektaris, G.; Z. Naturforsch. 2011, 66B, 850. http://dx.doi.org/10.5560/ZNB.2011.66b0850

32. Pedersen, D. S.; Rosenbohm, C. Synthesis 2001, 16, 2431. http://dx.doi.org/10.1055/s-2001-18722

\section{Graphical Abstract}

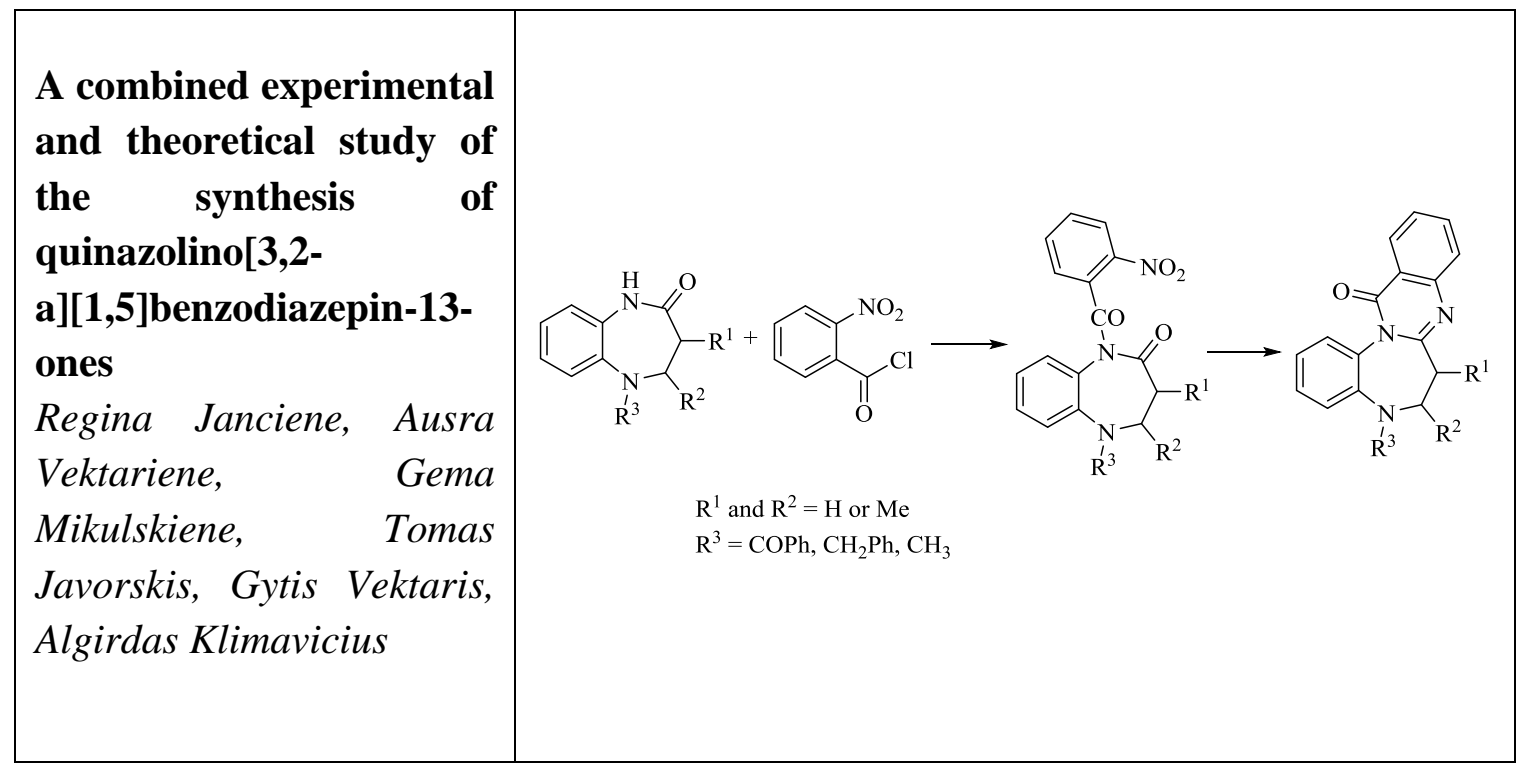

